\title{
Desenhos setecentistas na Sé de Belém
}

\section{Jussara da Silveira Derenji ${ }^{1}$}

RESUMO: Analisando um nicho e desenhos ao seu redor encontrados na restauração, concluída no ano de 2009, da Catedral de Belém (1748-1782), o artigo se ocupa das relações de trabalho artístico na região Norte durante o período colonial. $\bigcirc$ anonimato das profissões menos valorizadas, como entalhadores, pintores e escultores, exercidas por índios, negros e mestiços, contrasta com a documentação abundante reservada aos grandes nomes do período, a quem, de maneira genérica, é atribuída a autoria das obras. $\bigcirc$ artigo acompanha a trajetória do arquiteto régio Antonio Landi (1713-1791) e, através das obras dessa igreja, observa as mudanças técnicas e sociais do período de sua construção.

PALAVRAS-CHAVE: Artes decorativas. Período colonial. Norte brasileiro. Antonio Landi. Autoria artística. Catedral de Belém.

ABSTRACT: The article deals with artistic and social relations from the colonial period in the Brazilian Northern Region based on the assessment conducted within the restoration works of cathedral of Belém concluded in 2009, a church built from 1748 to 1782. The analysis of a niche and drawings of its surroundings were used on the development of the study. The unanimous workers of not valued professions at the time such as engravers, painters and black sculptors exercised by indigenous, backs and mestizos, contrasts with abundant documentation dedicated to well known names of the period to whom the authorship of the works is, generically, known. The article is dedicated to the trajectory of the regio architect Antonio Landi Antonio Landi (1713-1791) and the works of the cathedral it is possible to observe technical and social changes of the period of its construction.

KEY WORDS: Decorative arts. Colonial period. Brazilian. Northern region. Antonio Landi. Artistic authorship. Cathedral of Belém.

Fortemente influenciado pela Igreja Católica, Portugal cria, em suas colônias, vilas e cidades cujo centro gravita entre a igreja e o pelourinho. No Brasil, como nas outras possessões lusas, o poder religioso e o civil se confundem e entrelaçam-se de forma tangível, e é nas igrejas, talvez mais do que em qualquer outro tipo de construção, que podemos ler o lento evoluir não só do prédio como dos

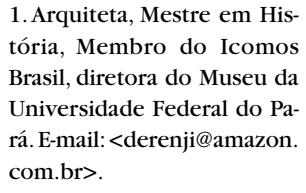

com.br $>$. 
2. Mesmo após a restauração da igreja em 2009, permanecia uma placa indicativa, colocada pela Prefeitura Municipal, dando a autoria do projeto a Antonio Landi (1713-1791); telas de Paulo Von Deschwauden eram tidas como de autoria de Perazzi, um pintor italiano; e os púlpitos em ferro, peças do fim do século XIX, eram confundidos com obra de talha.

3. Não procede, portanto, atribuição do projeto inicial ao arquiteto italiano Antonio Landi, que chega à região em 1753, quando a igreja já está na altura das torres. Em alguns estudos sobre a igreja de meados do século XX, foram frequentes os equívocos sobre autorias e datas, mas publicações recentes - e em especial, a reprodução de documentos coloniais feita pela pesquisadora Isabel Mendonça (2003) - não per mitem mais dúvidas sobre o andamento das obras do templo e seus personagens principais.

4. A informação provém de um requerimento dirigido a D. João $\mathrm{V}$, e de uma carta enviada por D. José I ao governador do Grão-Pará, documentos existentes, respectivamente, no Arquivo Histórico Ultramarino (Lisboa) e na British Library (Londres), reproduzidos por Isabel Mendonça (2003, p. 639; e p. 653-654).

5. Informação contida em Carta do Bispo D. Miguel de Bulhões a D. José, sobre a Sé, em documento existente no Arquivo Nacional da Torre do Tombo, Lisboa; ver Isabel Mendonça (2003, p. 294).

6. Schwebel foi um dos contratados pelo governo português, em 1750, para fazer parte de comissão demarcatória de limites entre terras de Portugal e Espanha, tendo sido encarregado de fazer as vistas ou panoramas dos lugares visitados pela expedição. próprios núcleos coloniais. Os períodos de progresso e de riqueza, as disputas e lutas, as fases de dificuldades com pestes e epidemias, as mortes das figuras notáveis, influenciavam o andamento das obras e deixavam marcas claramente identificáveis nas edificações religiosas brasileiras, cabendo ao arquiteto, historiador ou restaurador - ao pretender intervir nos edifícios - estudá-las e interpretálas. No caso específico da Matriz, depois Sé Catedral de Belém do Pará - sucessoras da antiga ermida de Nossa Senhora da Graça, erguida no início da colonização -, farta documentação apoiava as marcas históricas, ainda que restassem muitas imprecisões e, como habitualmente acontece, atribuições equivocadas lutassem por persistir².

Na construção das primeiras igrejas de Belém, a ermida de Nossa Senhora da Graça - dentro da primitiva fortaleza e erguida no início da colonização em 1616 - é indicada como a antecedente da igreja de mesma devoção que, logo a seguir, surge na praça fronteira. Igreja Matriz, ela se torna sede do bispado em 1719, ainda como uma construção em taipa e palha. Apenas em $1748^{3}$ começa a ser erguida ao seu redor uma nova edificação, continuando a parte interna a funcionar enquanto prosseguiam as obras.

Nesse ano, uma epidemia de sarampo acometeu e vitimou, em especial, os indígenas, a mão-de-obra disponível, quase única, para as construções na época. É significativo, portanto, que a edificação fique paralisada nesse período. Em fevereiro de 1749, recomeçam os trabalhos, estando à frente "das obras de pedraria" Manuel João da Maia e, em 1752, é emitida uma Carta Régia para tentar solucionar problemas da igreja relacionados com a sacristia e com as funções de sede do cabido, mostrando que, mesmo com dificuldades, a igreja continuava a ser erguida ${ }^{4}$. Documentos analisados por Isabel Mendonça demonstram que "em novembro de 1753 o corpo da igreja (a nave e o transepto) estava concluído. Faltava lançar a abóbada e acabar o frontispício e as torres, que então estavam na raiz das sineiras" ${ }^{5}$

Uma fonte importante para a análise do estado da construção em 1753 está nas vistas desenhadas por João André Schwebel ${ }^{6}$. Numa delas, datada desse ano e conservada na Biblioteca Nacional, a igreja aparece de forma clara, podendo ser vistas as duas torres baixas, na mesma altura de um frontão inacabado onde se esboça o nicho central (Figura 1).

Mais dois anos seriam necessários para fechar a abóbada e, no fim de 1755, o bispo anunciava a inauguração do prédio para o Natal. $\bigcirc$ mestre das obras Manuel da Maia confirmava que as torres e a fachada não estavam rematadas. No interior, consoante Mendonça, "o culto processava-se no cruzeiro do templo uma vez que a construção da capela mor fora adiada"7. Segundo a mesma autora, os recursos continuavam insuficientes, mas, em 1759, já se executavam trabalhos na capela-mor. Nesse ano, o bispo enviou uma nova planta da Sé à Corte. É nesta fase que se comprova o início da atuação do arquiteto italiano Antonio Landi ${ }^{8}$, na igreja. Os desenhos enviados são a planta e detalhes da decoração interior: "o guarda vento da nave, os retábulos das capelas, o púlpito e o órgão, riscados por Landi" deveriam dar ao bispado a "glória de ter a Sé mais nobre e sumptuosa da América"9 (Figura 2).

As obras pararam novamente em 1761 e só recomeçariam em 1766, 


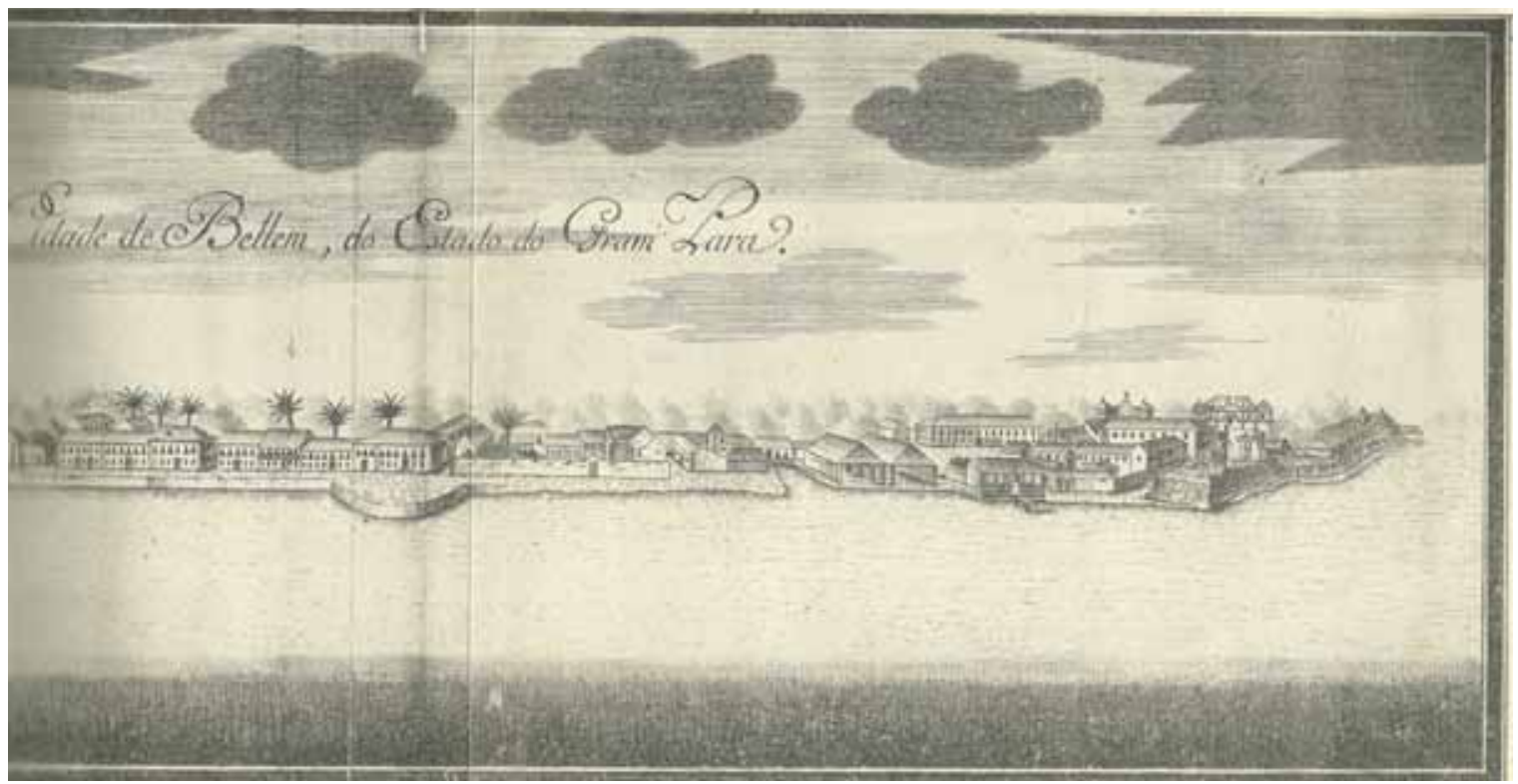

Figura 1 - João Schwebell. Detalhe da vista da cidade de Belém do Grão Pará, 1753, desenho a pena, Biblioteca Nacional, Rio de Janeiro. Na extrema direita aparece a fachada da Sé, em construção.

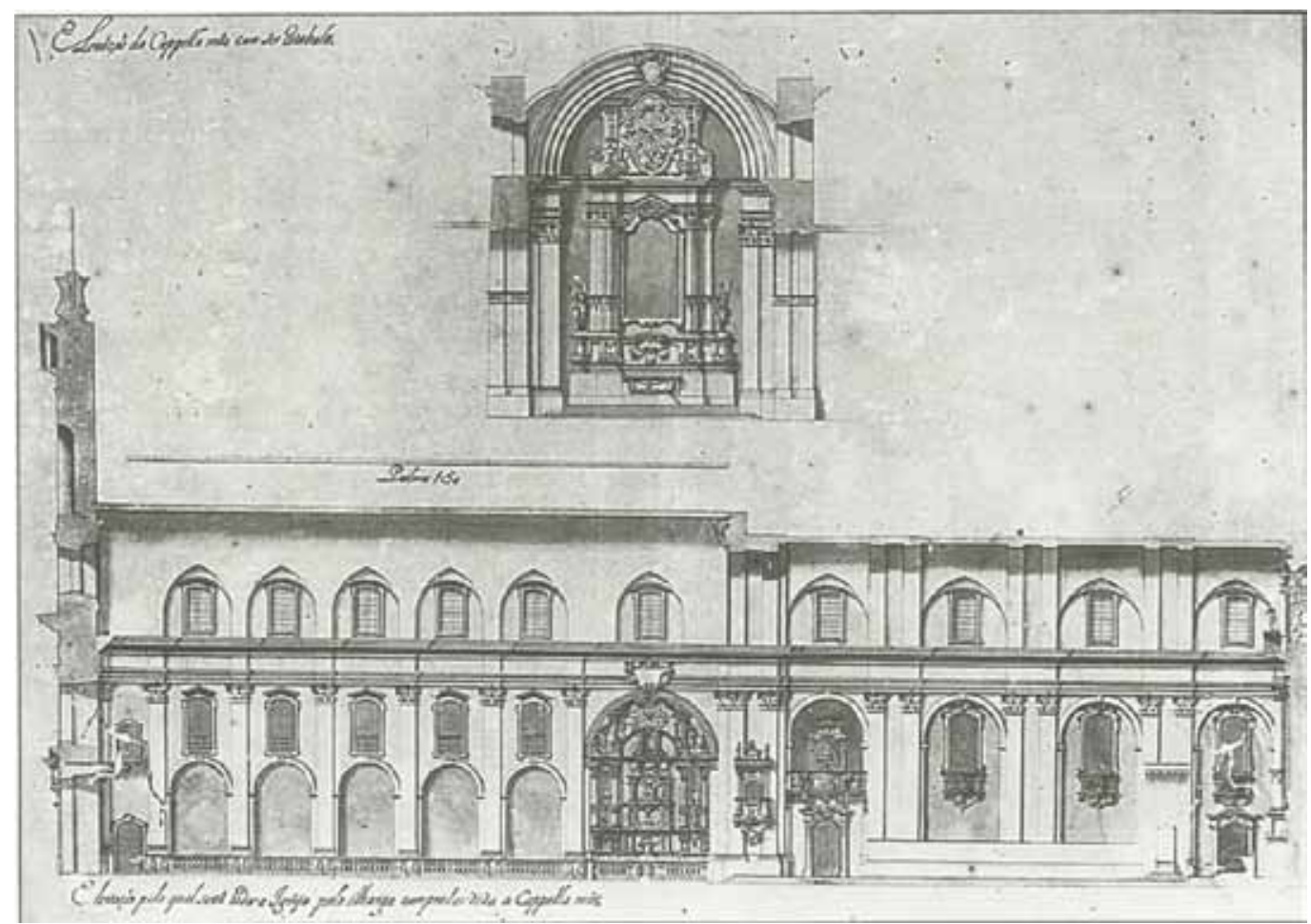

Figura 2 - Antonio José Landi (atribuição). Corte e retábulo-mor da Sé de Belém, desenho a pena aquarelados. Biblioteca Nacional, Rio de Janeiro. 
7. Cf. Isabel Mendonça (2003, p. 294), grifado no original.A fonte da informação é uma carta do Bispo a Francisco Xavier de Mendonça Furtado sobre a Sé, existente na Biblioteca Nacional de Lisboa; ver também Isabel Mendonça (2003, p. 686)

8. Antonio Landi chegou a Belém do Pará com quase 40 anos, em junho de 1753 , depois de ter passado três anos em Lisboa, já contratado pelo governo português para fazer parte de uma comissão demarcadora de limites entre terras de Portugal e de Espanha nas colônias americanas Começaria a ser reconhecido pelo talento para a arquitetura desenvolvendo, por quase 30 anos, projetos definidores de mudanças significativas para os núcleos urbanos do Grão-Pará. Desses palácios, igrejas, capelas, residências urbanas e rurais, e diversos prédios oficiais existe farta documentação e, em alguns casos, desenhos originais que comprovam as inovações trazidas por seus projetos. Em Belém, a capital, são de sua autoria: Palácio de Governadores, igreja de Santana, capela de São João, Hospital Militar, além de residências e capelas também situadas nas imediações, como as construídas no engenho de Murutucu, uma de suas propriedades. No interior da província, e principalmente em Barcelos (Amazonas), projetou igualmente palácios e igrejas. Em 1784, apesar de sua posição na vida social e econômica da capital, e de sua idade, as autoridades portuguesas ordenam sua volta a Barcelos, onde estivera e trabalhara 30 anos antes, durante a grande expedição demarcatória conduzida por Mendonça Furtado. Nessa vila amazonense, adoece gravemente em 1788 e retorna a Belém, onde morre no ano de 1791. Cf. Isabel Mendonça (1999a), idem (1999b), idem (2003).

9. Idem, p. 699, segundo carta do Bispo a Tomé da Corte ano em que é solicitada uma vistoria técnica à capela-mor. Essa visita técnica só é possível porque a cidade recebera, desde a metade do século XVIII, engenheiros militares, dentre eles Landi, contratados pelo governo português para a Comissão Demarcadora de Limites. Observa-se, aqui, uma das formas como a presença desses novos profissionais especializados influenciaria na qualidade dos serviços executados no período. A capela-mor foi vistoriada por Gaspar João Gronsfeld ${ }^{10}$ e por Manuel Calheiros, que consideraram as paredes aptas a suportar a abóbada. Assim autorizadas, as obras recomeçam e, no dia 8 de setembro de 1771, o Santíssimo é transferido do cruzeiro para a nova capela-mor.

Apenas em 1782, quando ocorre a consagração do altar do transepto dedicado a Nossa Senhora de Belém, as obras da Sé são consideradas terminadas ${ }^{1}$. Os trabalhos finais foram realizados durante a gestão do bispo Dom Frei João Evangelista Pereira e incluíram o remate do frontispício e da cabeceira do templo.

Não é objetivo deste texto esgotar as informações disponíveis sobre a longa construção da Sé de Belém, fartamente documentada, como demonstram estudos de pesquisadores que se dedicaram ao assunto ${ }^{12}$. A esta análise interessa um fato em especial: a existência de um nicho - e desenhos em seu entorno - até agora desconhecido.

Em sua trajetória de ermida a capela, de matriz a catedral, de igreja setecentista ao ecletismo das reformas do século XIX, a restauração mais extensa que a Sé de Belém conheceu foi concluída em setembro de $2009^{13}$. E, se nela muitas hipóteses foram comprovadas, outras indefinições surgiram (Figura 3). $O$ nicho descoberto na capela-mor é, sem dúvida, a maior delas. É nesse nicho inesperado e inusitado, e nos desenhos existentes em seu entorno imediato, que estamos interessados. A oportunidade de observar as pinturas e o nicho sobre o altar-mor foi única, pois, após a reabertura do templo, o vão ficou, como desde - século XIX ${ }^{14}$, encoberto por uma pintura semicircular que representa a Natividade ${ }^{15}$ (Figuras 4 e 5).

Na restauração, ao retirar essa tela situada no ponto mais alto da parede de fundo da capela-mor, verificou-se existir um nicho ao qual nenhuma das fontes até então conhecidas fazia referência. Bastante profundo, e alto o suficiente para conter uma imagem maior que o tamanho natural, ele teve seus ornamentos arrancados para tornar plana a parede de fundo e, possivelmente, receber a tela citada. Na parte externa do nicho ficaram as marcas do elaborado desenho da moldura arrancada (Figuras 6, 7 e 8).

Se nada se sabia dele, mais intrigante ainda era a existência, na mesma parede de fundo, de vários grafites (se assim os podemos chamar) desenhos de detalhes arquitetônicos, animais e esboços de figuras; e uma data: 1776. Os desenhos - de traços largos, de forma geral bastante firmes e linhas simples, mas sem relação com o entorno - mostram um ou mais desenhistas com alguma habilidade e capacidade de observação; assim como o nicho demonstra um projetista e executores de formação se não erudita, pelo menos capacitada à tarefa empreendida (Figuras 9, 10 e 11).

Para situar e estudar a capela-mor e seu retábulo, foram consultadas 


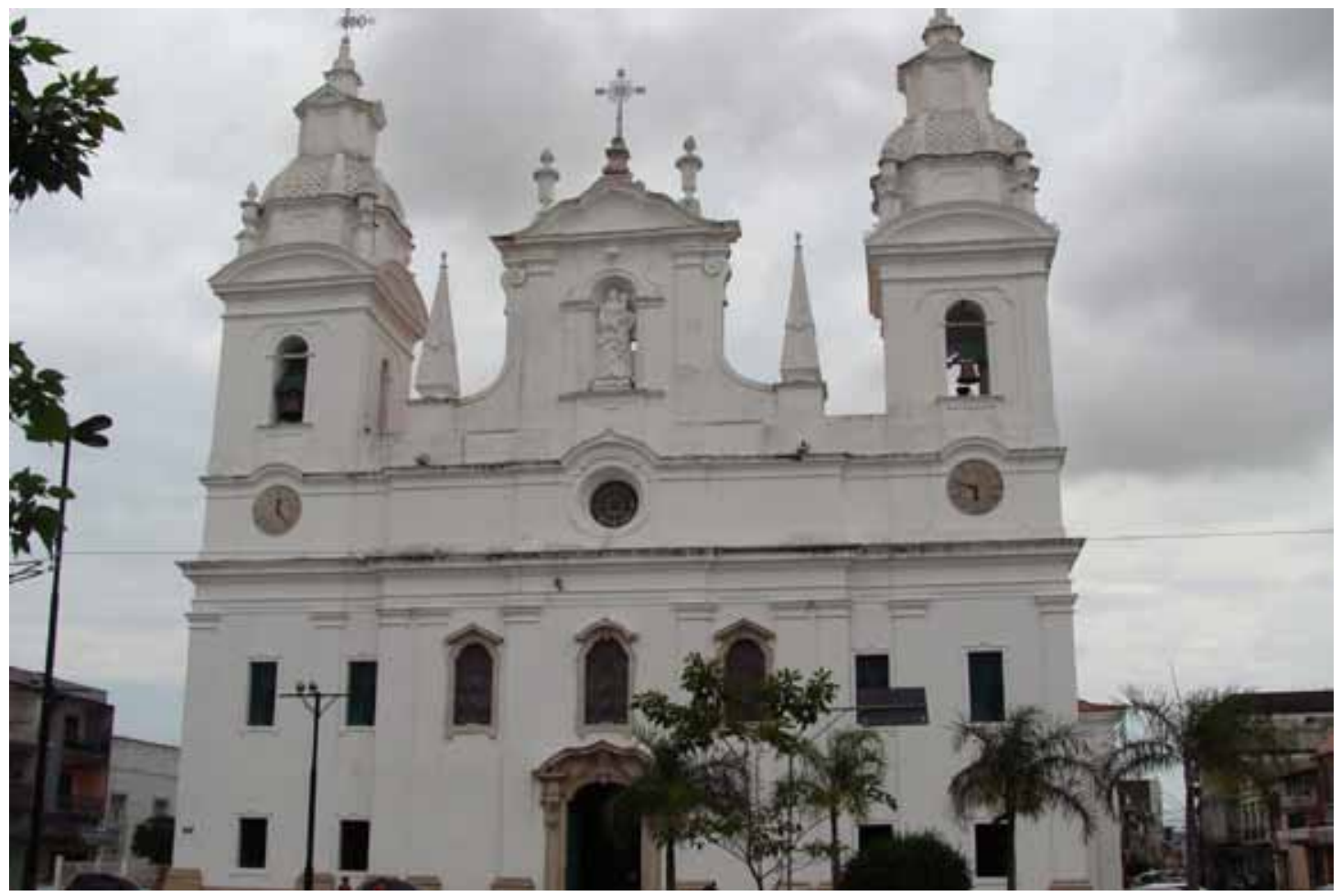

Figura 3 - Fachada da Sé de Belém após a restauração de 2009. Fotografia de Jussara Derenii, 2011.

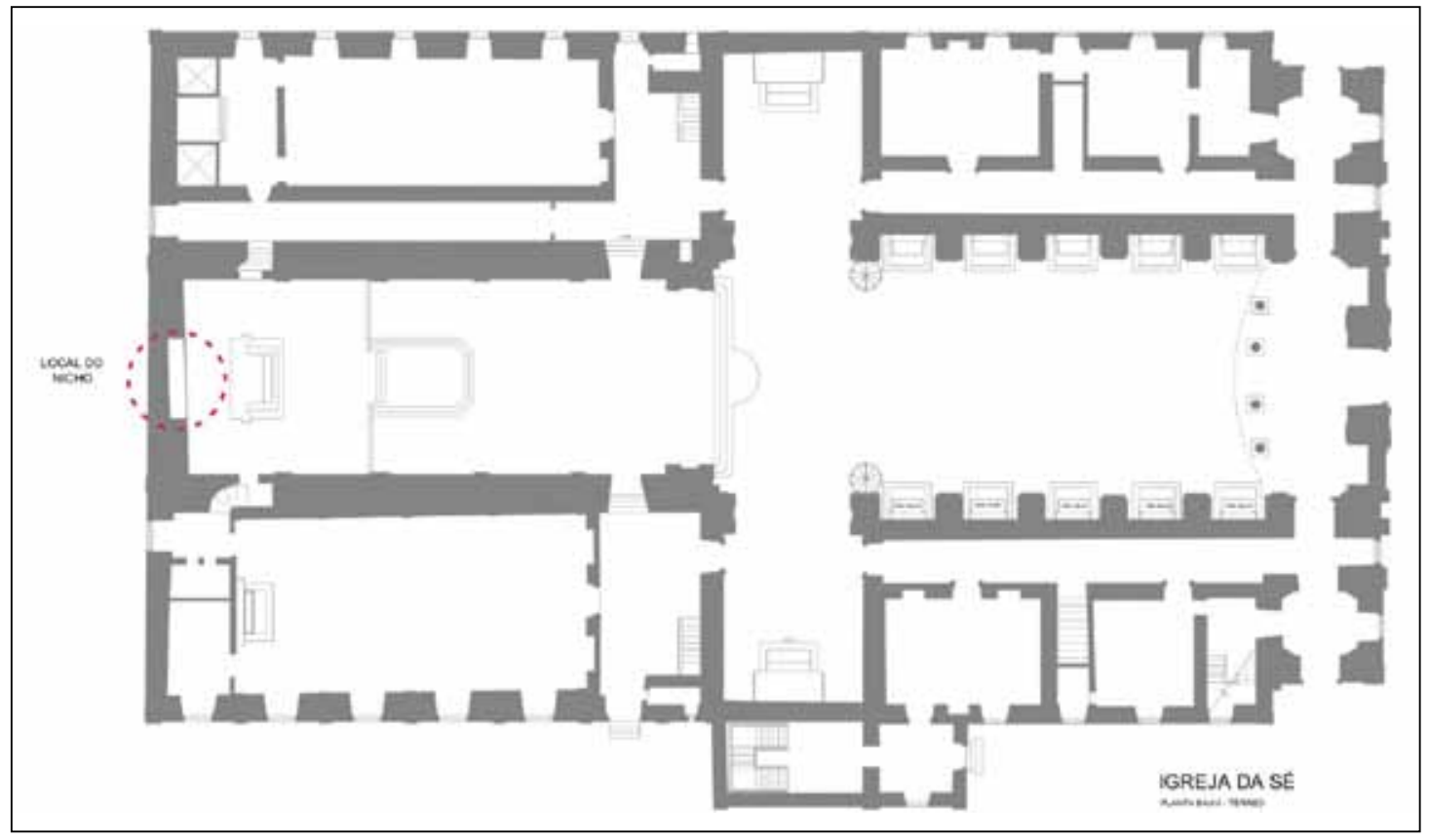

Figura 4 - Planta da Sé de Belém, com marcação da posição do nicho. Arquivo da autora. 


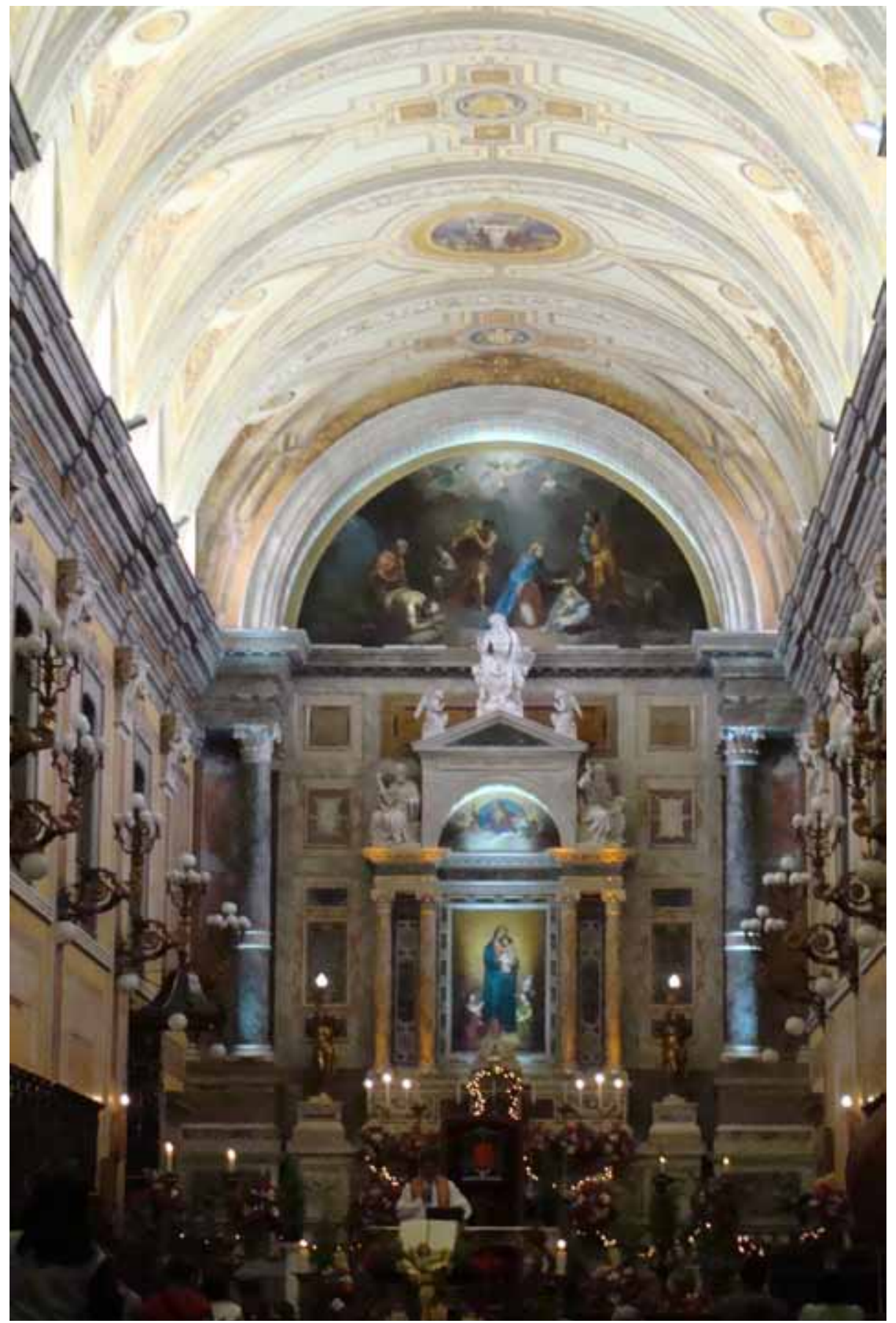

Figura 5 - Nave da Sé de Belém com a configuração atual. $\bigcirc$ nicho localiza-se atrás da tela semicircular no extremo superior da foto. Fotografia de Jussara Derenji, 2011. 


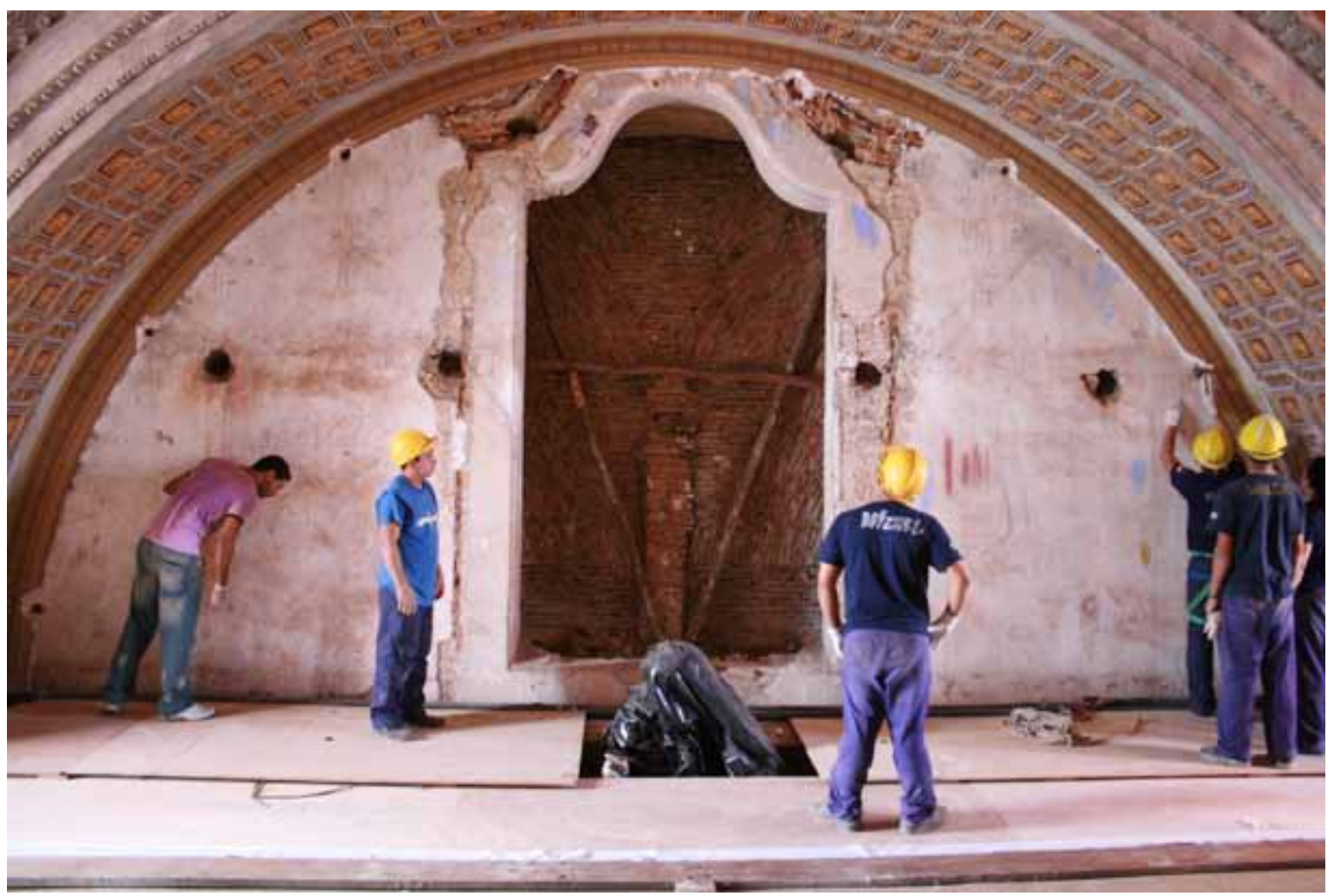

Figura 6 - Nicho localizado durante as obras de restauração iniciadas em 2009. Fotografia cedida pela empresa Construtora Link da Amazônia.

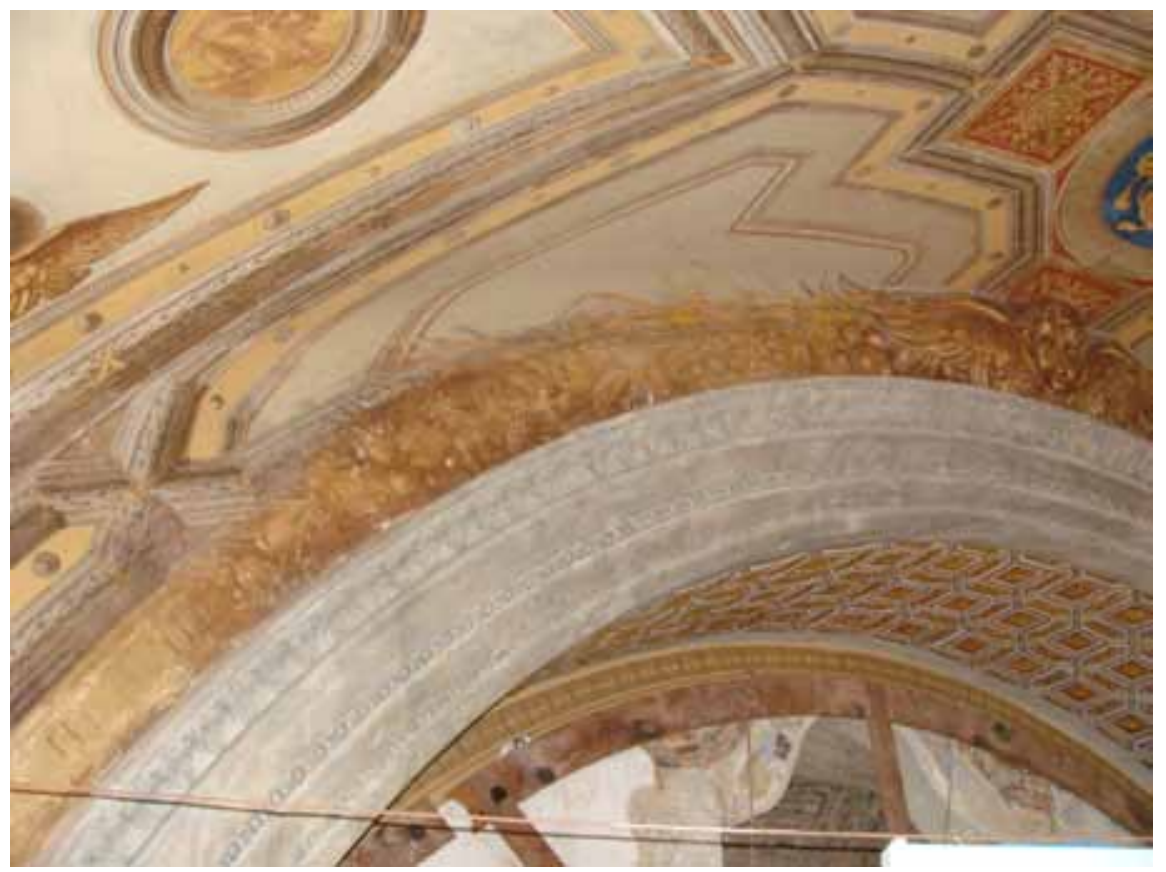

Figura 7 - Detalhe da capela-mor da Sé de Belém. Fotografia de Jussara Derenji, 2011 . É possível perceber que houve o encobrimento da parte superior do nicho do século XVIII, provavelmente no período em que foi executada a decoração da catedral por artistas italianos no fim do século XIX.

Annals of Museu Paulista. v. 19. n.1. July.-Dec. 2011. 


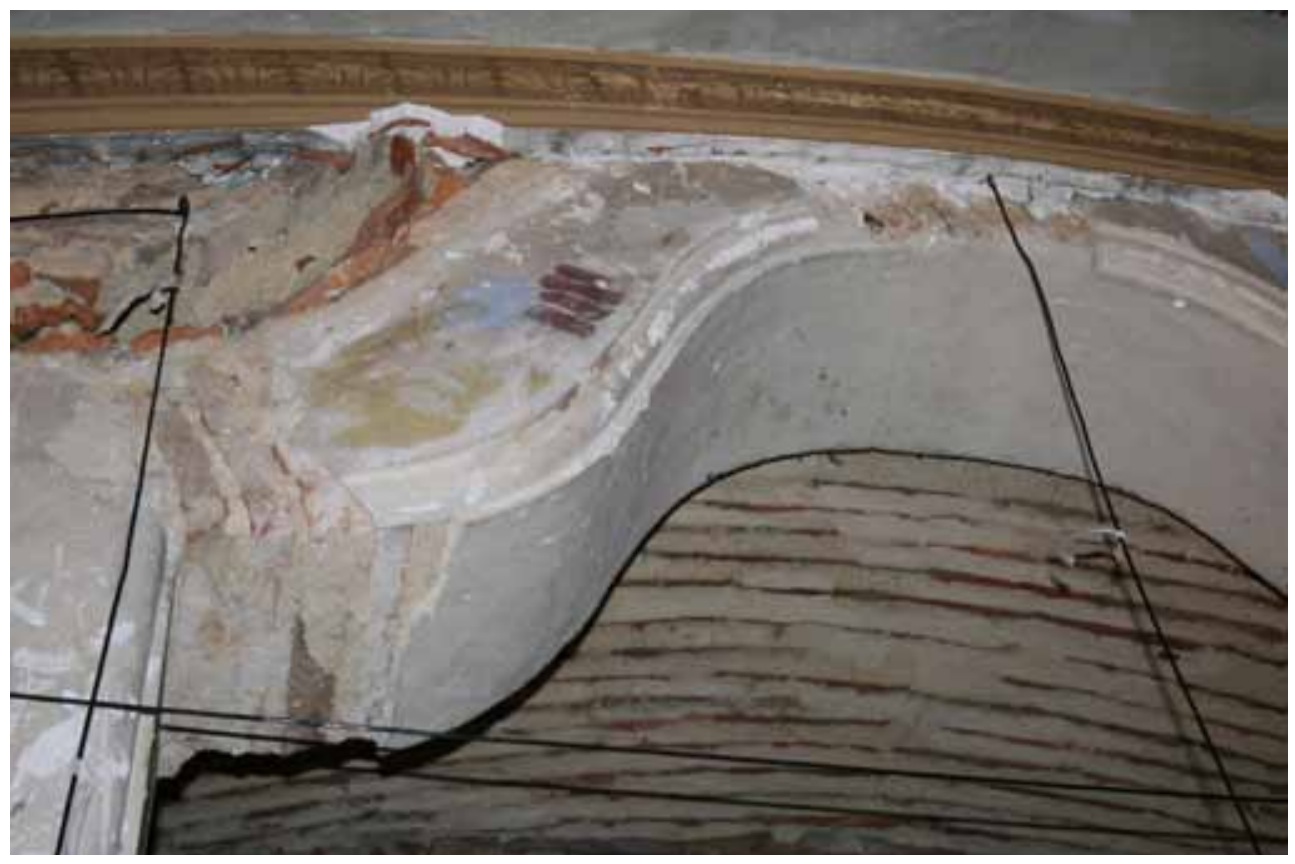

Figura 8 - Detalhe do nicho. Fotografia de Jussara Derenii, 2009, cedida pela Link da Amazônia.

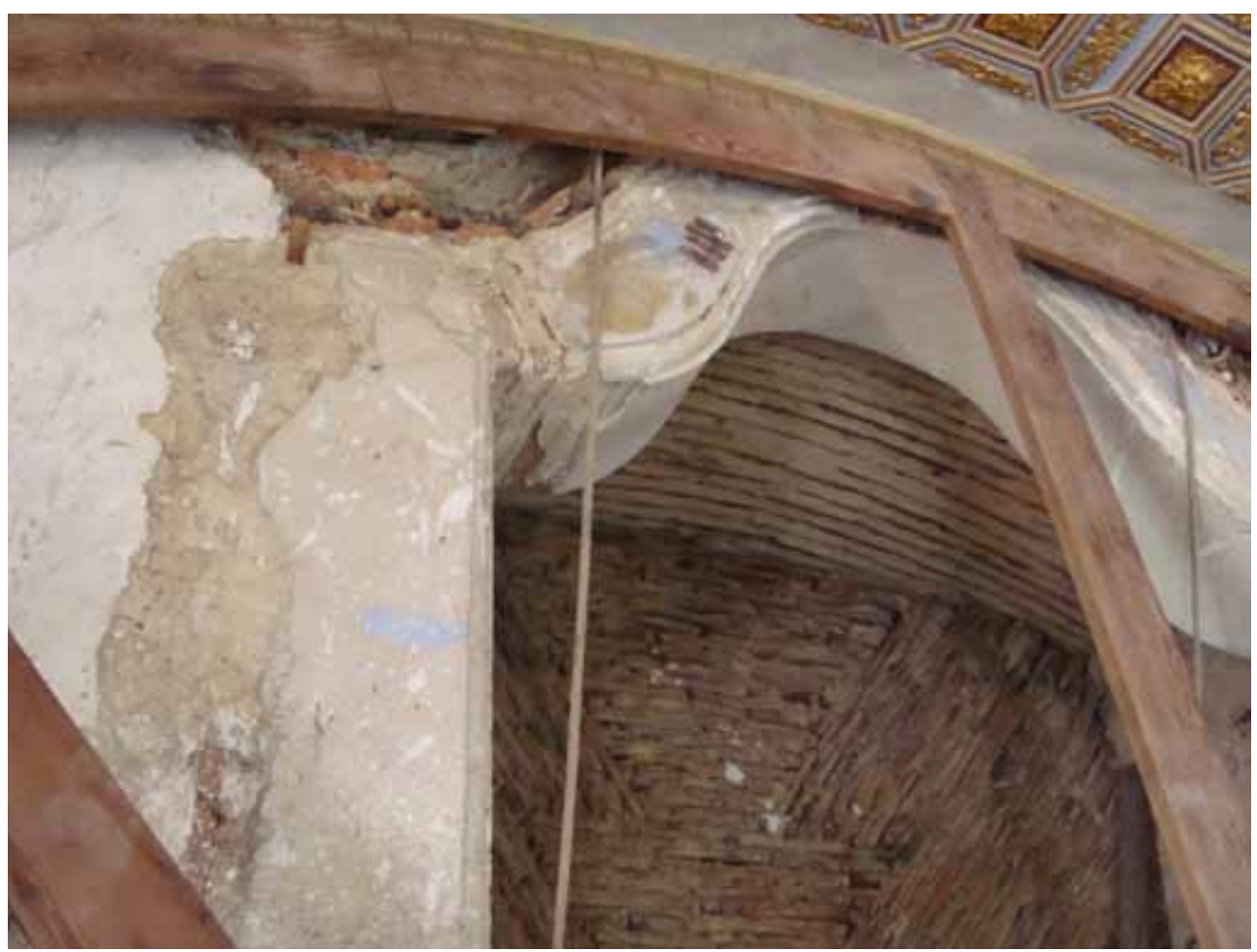

Figura 9 - Detalhe interno do nicho, no qual se percebe o desenho da tijoleira que compõe o seu fundo e sua abóbada. Fotografia de Jussara Derenii, 2009. 


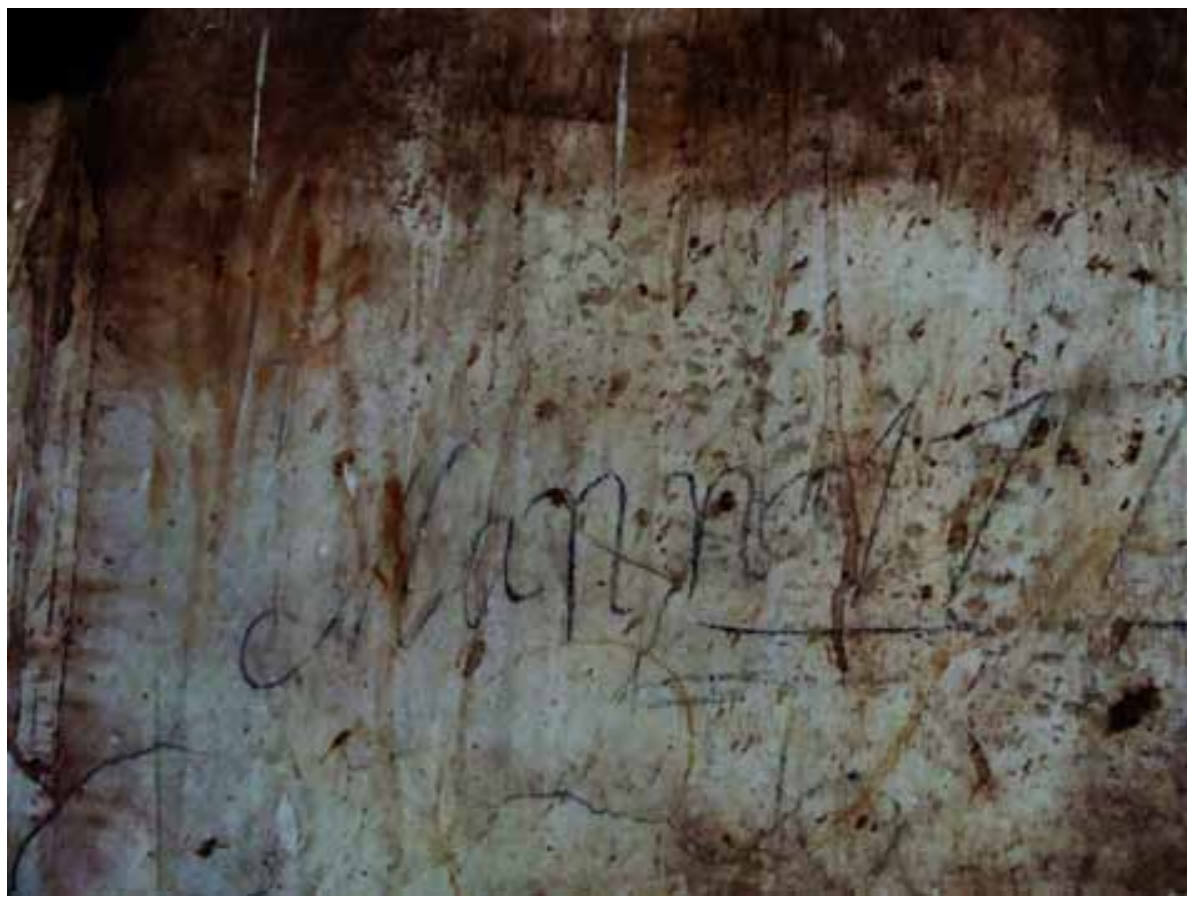

Figura 10 - Desenhos localizados no entorno do nicho. Fotografia de Jussara Derenii, 2009 .

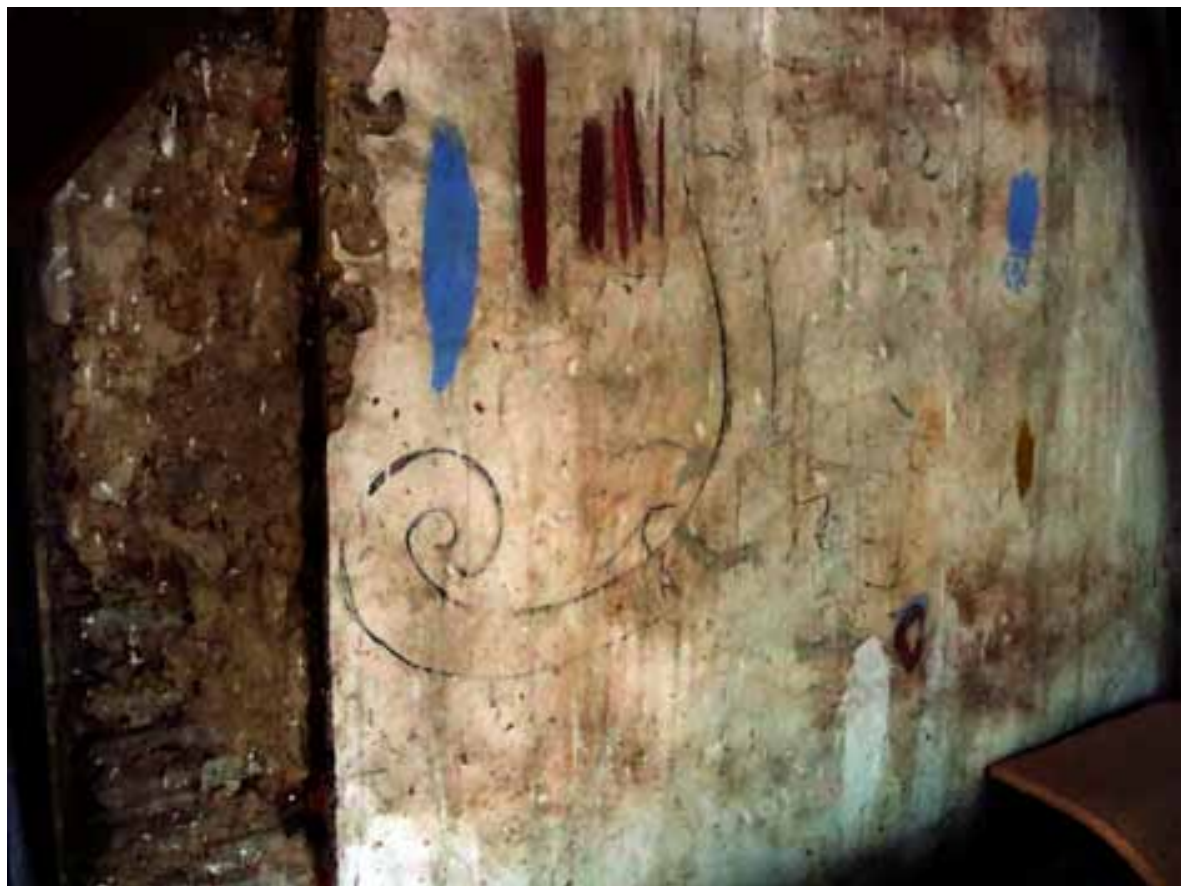

Figura 11 - Desenhos localizados no entorno do nicho. Fotografia de Jussara Derenji, 2009. À esquerda é possível perceber a marca de ornamento arrancado. 
Real remetendo, dentre outros, os riscos da Sé; documento do Arquivo Histórico Ultramarino.

10. Outro dos contratados pelo governo português em vários pontos da Europa em 1750. O nome deste engenheiro é citado de diversas formas: Gronfeld, em Marcos Carneiro de Mendonça (1963,v.3, p.617) e em Donato Mello Junior (1970, p.23); Gronfelt, Amaral Lapa (1978, p.145-146); Gronsfeld é usado não só em Nestor Goulart Reis Filho (2000, p.283 e 402)mas também em Augusto Meira Filho (1976, p.687) e em onze citações no texto de Isabel Mendonça (2003)

11. Ainda que em 1794 o Frei Caetano Brandão continuasse a pedir recursos para obras; cf. Isabel Mendonça (2003, p. 294)

12. A bibliografia sobre a construção da Sé de Belém é muito extensa: Alexandre Rodrigues Ferreira (1972); António Baena (1969; 1. edição de 1838); Paul Marcoy (1867); Robert Smith (1951); Ernesto Cruz (1974,1. edição de 1953); Germain Bazin (1956); Donato Mello Junior (1973); Augusto Meira Filho (1976); monsenhor Americo Leal (1979); Isabel Mendonça (1999a, 2000 e 2003); Myriam R. Oliveira (2003); e Jussara da Silveira Derenji e Jorge Derenji (2009). Deve-se salientar que os documentos utilizados nas análises por todos os autores citam, basicamente, as mesmas fontes primárias, acessíveis em arquivos nacionais e estrangeiros. O único texto que reproduz os documentos originais, em sua integra,é o de Isabel Mayer Godinho Mendonça (2003). Não sendo o objetivo deste artigo propor um estudo sobre a construção da Sé e sim sobre um particular elemento arquitetônico nela situado, para elaborar as análises constantes deste texto optou-se pela leitura dos documentos compilados $\mathrm{e}$ publicados recentemente fontes do século XVIII que conduziam à ałuação do arquiteto Antonio Landi na igreja e na decoração do seu interior. Chegado a Belém em 1753, logo se destacou pelo talento para a arquitetura, tendo obtido vários encargos importantes em Belém e no interior do Estado do Grão-Pará. Os desenhos para a Sé, anteriormente citados, foram feitos antes de fevereiro de 1759, data em que D. Frei Miguel de Bulhões, bispo no período, os envia à Corte ${ }^{16}$. No envio, ele se refere especificamente ao setor da igreja que nos interessa, dizendo "enquanto à capella mor actualmente se trabalha nas paredes". Dos desenhos enviados por Bulhões, saliente-se que só um está assinado por Landi - o do retábulo do Santíssimo -, Isabel Mendonça assegura, porém, que o "traço utilizado e a grafia das legendas identificam um mesmo autor" $^{\prime 17}$. O bispo Bulhões tinha grande interesse na igreja, o que coincidia com a intenção e o caráter fortemente religioso das obras do reinado de D. João $V$, em que ela fora iniciada. Os esforços pela conclusão das obras esmorecem a partir de 1760, quando é nomeado bispo do Pará Dom Frei João de São José. Com fama de irônico, de intelectual sempre cercado de livros que parecia não apreciar o ambiente local, esse religioso interrompe sem maiores explicações as obras da Sé. No mesmo ano, Landi vai se destacar nas coreografias das comemorações, no Pará, pelo casamento de D. Maria com o Infante D. Pedro em Lisboa. Carta do governador ao rei $\mathrm{D}$. José diz que "por três noites se iluminaram os edifícios da cidade, fazendo-se nas chamas de tantas luzes bem patentes as alegrias dos fieis vassalos de Vossa Majestade" 18 . Além do sucesso nas celebrações, Landi tem outros fatos a comemorar: ainda em 1760 são mandadas a Lisboa as plantas do Palácio dos Governadores, desenhadas por ele; é lançada a primeira pedra de Santana, outro projeto de sua autoria; e ele remete para o Reino uma grande carga de cacau. Tudo parecia correr bem para o arquiteto até chegar à cidade a ordem real de retorno de todos os componentes das antigas Comissões de Limites, entre eles, Landi. Só em 1763 ele conseguiria reverter ordem de retorno ao Reino, permanecendo na capital do Pará.

O bispo, por sua vez, nesse período se ocupava em intermináveis devassas nos bens dos jesuítas, expulsos em 1759, cujas posses atraíam cobiça na Colônia. Por contrariar interesses locais e desafiar o poder real, Frei João é mandado de volta ao Reino em 1763, e, não por acaso, sua saída, sob a acusação de ter livros proibidos, coincide com o início da ałuação da Mesa da Inquisição no Pará. Ainda no mesmo ano, uma epidemia de bexigas dizima a população mais pobre de Belém, em especial os índios, o que também não favorece o reinicio das obras.

Por mais três anos os trabalhos na Sé permaneceriam paralisados. Landi, estranhamente, não seria chamado para a vistoria técnica da capela em 1766, mesmo tendo feito desenhos para a decoração e para os retábulos da igreja.

Sabemos que, na ocasião do envio dos desenhos do retábulo (entre outros da Sél, Landi lutava por afirmar-se e permanecer no Pará, urdia muitos projetos arquitetônicos e era comerciante empreendedor, detendo inclusive a administração da olaria da cidade. Também em 1766, inaugurava-se a Igreja do Carmo, onde Landi tinha trabalhado no adossamento da nova fachada; e o 
arquiteto adquiria a fazenda e o engenho de Murutucu, aos quais, posteriormente, acrescentaria a fazenda de Utinga. Até 1772, Landi ficaria envolvido em nova série de obras oficiais importantes: palácio, quartéis, hospital real e Capela de São João, onde se executam detalhadas pinturas em trompe l'oeil. No ano citado nos desenhos ou grafites da capela-mor (1776), das atividades de Landi nada existe registrado. Em 1777, ele figura dentre os devedores da extinta Companhia de Comércio do Pará "como bem estabelecido"19; e, em 1778, aparece na relação dos moradores de Santana, já viúvo e com a filha Ana. Em sua casa trabalhavam um criado e uma criada; e possuía quarenta e sete escravos ${ }^{20}$. Em 1782, inaugura a lgreja de Santana, projeto seu que empregava escravos e recursos próprios. No ano seguinte, trazendo dois desenhistas, Alexandre Rodrigues Ferreira chegaria ao Pará e, durante sua permanência de nove anos, receberia desenhos cedidos pelo arquiteto italiano documentando várias de suas obras executadas na região (hoje, tais desenhos constituem os mais importantes referenciais dessas obras).

Existem dois conjuntos remanescentes de desenhos para a Sé de Belém. $\bigcirc$ primeiro deles é o que está preservado na Biblioteca Nacional do Rio de Janeiro e contém uma elevação do altar-mor "com seu retábulo"; o segundo conjunto é o dos desenhos constantes na iconografia reunida por Alexandre Rodrigues Ferreira ${ }^{21}$, com um desenho assinado por Landi - Retábulo da capelamor da lgreja catedral da cidade do Pará. Esses desenhos, no que se refere ao retábulo da capela-mor, ponto de interesse deste texto, mostram que, no primeiro conjunto citado, o embasamento do retábulo tem mesa de altar em forma de urna; logo acima, um corpo central com tela emoldurada, tendo aos lados pares de colunas e ao alto um corpo levemente mais estreito (Figura 12). No tímpano está figurado um resplendor com raios e nuvens, tendo ao centro a pomba do Espírito Santo, motivo recorrente nos desenhos do arquiteto Landi. Nas laterais do corpo central estão grandes figuras alegóricas. Mendonça salienta, porém, que o projeto executado não foi esse e, sim, o que faz parte da iconografia reunida por Alexandre Rodrigues Ferreira - "o segundo projeto, que veio a ser realizado era de um retábulo de maiores dimensões" 22 . Diferente do anteriormente citado, tal retábulo ocuparia toda a parede de fundo da igreja, mantendo, todavia, como ponto focal, o grande esplendor com o Espírito Santo. As figuras alegóricas tinham sido transferidas para o nível mais alto, acrescidas de vasos floridos, de guirlandas e de outros detalhes decorativos (Figura 13).

Do retábulo existente na Sé antes do atual ${ }^{23}$, temos como testemunha direta Antonio Baena, que o descreve, ainda em 1829, como "obra de talha aperolada com florões, vasos, grinaldas espirais dos fustes das colunas torcidas, métopas, capitéis, bases, cornijas e seus dentilhões, tudo dourado e os acrotérios da cor de alabastro [...] $\bigcirc$ retábulo do altar-mor tem no alto um grande painel de Nossa Senhora da Graça, obra do ínclito engenho de Pedro Alexandrino de Carvalho"24. Alguns pontos da descrição do retábulo feita por Baena, publicada em 1838, parecem comprovar a afirmação de Mendonça, de que o segundo projeto foi o executado, em especial quando ele descreve as guirlandas em espiral por essa autora. Deve ser salientado, ainda, que nenhum dos autores (ou dos documentos) consultados cita o nicho ou os desenhos objetos deste artigo, ou a eles se refere.

13.A obra foi conduzida pela Secretaria de Estado de Cultura e executada pela Construtora Link da Amazônia.

14. Supomos que o período de encobrimento tenha sido, porém, bem maior, conforme hipóteses da autora, desenvolvidas a seguir

15. Ou Presépio, do artista italiano Lottini, datada de 1881.

16. Desenhos, referidos como "riscos da Sé", estão atualmente na Biblioteca Nacional do Rio de Janeiro. Isabel Mendonça diz que, provavelmente, trata-se do conjunto de plantas e desenhos citados no documento 63 , por ela reproduzido na página 699 São plantas, cortes longitudinais, detalhes de púlpito, do órgão, entre outros, constando, ainda, o corte transversal do retábulo do altar-mor e uma elevação do mesmo; ver Isabel Mendonça (2003).

17. Idem, p.358

18. Idem, p. 348, 711-712. A autora se baseia em minuciosa descrição das festas feita pelo padre João Ângelo Brunelli (em carta datada de 12 de novembro de 1760 , enviada a seus familiares na Itália e conservada na Biblioteca Nacional do Rio de Janeiro).

19. Idem, p 574.

20. Este não foi o maior número dos de sua propriedade: Landi chegou a ter mais de oitenta escravos.

21. O baiano Alexandre Rodrigues Ferreira (17561815) estudou em Portugal, onde se gradua em Filosofia e Ciências Naturais em 1779. Por influencia do botânico real Domingos Vandelli, é in- 
Figura 12 - Desenho para retábulo na Sé, Biblioteca Nacional, Rio de Janeiro. Detalhe da figura 2.

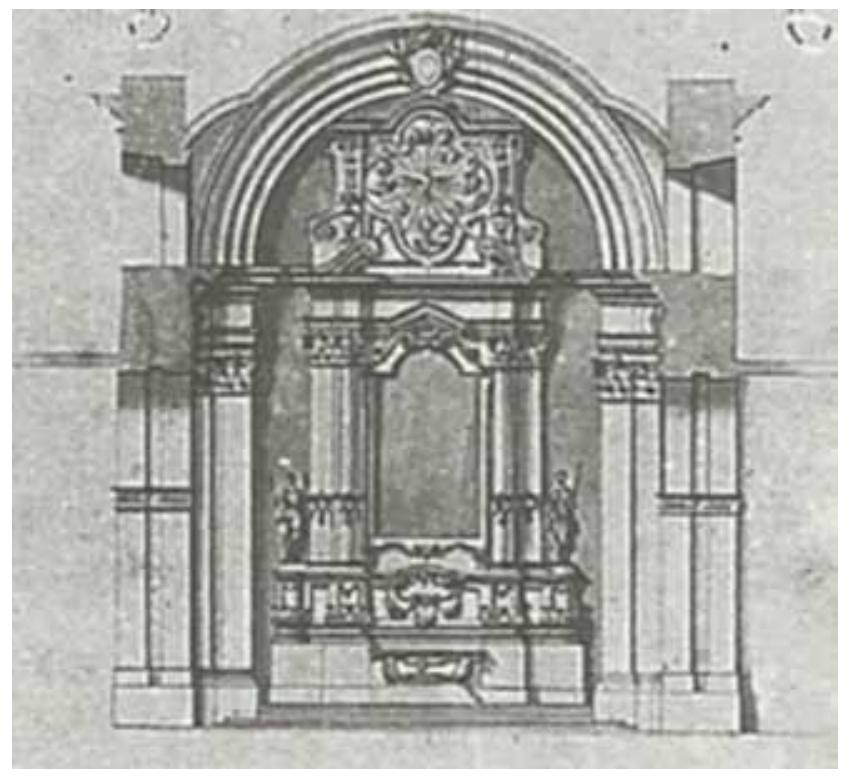

Figura 13 - Retábulo da capela mor da Igreja Catedral da Cidade do Pará. Alexandre Rodrigues Ferreira. Viagem Filosófica. Iconografia, Folha 8. 
das colunas torcidas, assim como os tríglifos e as métopas, inexistentes no desenho anterior $^{25}$. Porém, é certo que, mesmo tendo projetos desenhados desde 1759, o retábulo do altar-mor só poderia ser feito depois de ser terminada a capela-mor, o que ocorre somente em 1771. Temos, ainda, um período de, aproximadamente 26 , dez a onze anos até 1782 (quando as obras da Sé são dadas por terminadas), para que o retábulo fosse executado.

A comparação dos desenhos do retábulo da capela-mor com o nicho agora encontrado apresenta-se como um tema instigante, para o qual podem levantar-se várias questões que nos aguçam a refletir. A principal delas parece ser a pertinência de considerar-se que o nicho possa ter feito parte do retábulo landiano. Nesse sentido, retomando a análise dos desenhos de planta baixa e do corte transversal datados de 1759, alguns pontos chamam a atenção. $\mathrm{Na}$ parede de fundo, em corte, aparece - exatamente na parte mais alta, acima da cimalha - uma interrupção no traço, que poderia ser um vão aberto na parede; e, em sua projeção, parece estar representado o esplendor desenhado por Landi. Já na planta baixa, atrás do altar, é também figurado um vazio: uma janela ou nicho. Existiria então, em 1759, o nicho agora encontrado? Se existisse, poderia ser atribuído, com seu desenho elegante e ornamentos elaborados, ao mestre Manuel João da Maia de quem tão pouco sabemos?27 $\bigcirc$ nicho encontrado parece não ter tido acabamento interno, sugerindo um fundo decorativo de material efêmero, talvez tecido ou madeira pintada. Porque, no entanto, fazê-lo tão profundo se a altura onde estava inviabilizaria a visibilidade da parte interna?

Os ornamentos nas laterais externas, posteriormente arrancados, podem, porém, ter sido apostos a uma forma mais contida e singela. Teria Landi deixado permanecer naquele local um nicho pré-existente, integrando-o à sua composição? ${ }^{28}$ Apoiando esta hipótese, nota-se que comparações feitas pela equipe de restauro ${ }^{29}$ entre as dimensões do nicho, agora descoberto, e a parte central do projeto de Landi mostram um ajuste aproximado, exato na largura e adaptado na altura, para o novo desenho.

Em italiano, existe uma expressão que pode ser traduzida como "arquitetura de gaveta", ou seja, arquitetura desenhada e guardada em arquivos sem ter sido executada, ou tendo sido executada de forma diferente do projeto. Poderia, assim, a doação dos desenhos de Landi a Alexandre Rodrigues Ferreira referir-se a um projeto que o arquiteto concebera, mas não corresponder na íntegra ao que fora realmente construído? Convém lembrar que, entre a concepção do altar (1759) e sua execução, passam-se pelo menos treze anos; e mais dez seriam necessários até a chegada de Alexandre Rodrigues Ferreira à região. Ou seja, entre os desenhos iniciais e a doação dos mesmos ao naturalista Ferreira, decorreram, aproximadamente, vinte e cinco anos.

A resposta a algumas das questões suscitadas está, acreditamos, novamente em Baena, que descreve o retábulo como "obra de talha aperolada", ou seja, o altar que ocupava todo o fundo da igreja era em madeira talhada, um cenário onde figuravam florões e colunas, com relevos e estátuas ${ }^{30}$. $\bigcirc$ retábulo citado por Baena não é pintado em trompe l'oeil, como o de São João, nem em dicado, em 1783, para uma importante comissão cientifica no Brasil, tarefa que leva a cabo, de 1783 a 1792 , com enormes dificuldades $\mathrm{e}$ perdas pessoais. Botânico, geólogo, biólogo, etnógrafo, antropólogo, Ferreira foi também arguto observador político. Sua obra, vastíssima, perdeu-se em grande parte na volta a Portugal, mas a publicação, em 1972, da iconografia da sua Viagem Filosófica pelas capitanias do Grão Pará, Rio Negro, Mato Grosso e Cuyabá, divulgou um conjunto de desenhos de arquitetura a ele oferecido por Antonio Landi.

22. Cf. Isabel Mendonça (2003, p. 471); grifo nosso.

23. Desconhecemos a fonte da afirmação de Isabel Mendonça (2003) sobre a execução do segundo desenho. Provavelmente, segue a lógica das datas em que os desenhos foram dados a Alexandre Rodrigues Ferreira por Landi. Se o desenho foi dado após 1783, quando o baiano chega ao Pará e a Sé está terminada,o desenho deveria coincidir com o que fora executado.

24. Cf. Antonio Baena (1969 p. 186).

25. Ver nota 21.

26. O naturalista baiano se refere à capela dizendo ter sido o bispo Evangelista Pereira, que assumiu em 1772 , quem "cobrio a capella-mor $\mathrm{e}$ completou-a de tudo"; cf. Isabel Mendonça (2003, p. 471).

27. Pelo que sabemos, não se trata de Manuel da Maia, engenheiro militar que trabalhou na reconstrução da Lisboa pós-terremoto, embora o período de vida de ambos coincida. Em 1750, o mestre da Sé substituiu José Lopes como mestre das reais obras em Belém.

28. O nicho apresenta entalhes e ornamentos internos com formas geométricas, o 
que reforça a hipótese de sua existência anterior.

29. Ver Roseane Norat (2009).

30. Cf. António L. M. Baena (1969, p. 186). Para isso, supõe-se que o altar em madeira tenha se mantido íntegro entre o fim dos trabalhos (1782) e a descrição de Baena (1838), ou seja, por quase cinquenta anos.

31. Cf. Américo Leal (1979, p. 70).

32. Idem, ibidem.

33. Existe uma grande imagem da padroeira no nicho da fachada. Segundo informações de João Veloso, restaurador do IPHAN, originalmente era policromada, embora esteja atualmente pintada de branco. Não existindo medição precisa da referida imagem, não foi possível determinar se ela poderia ter sido colocada no nicho interno. alvenaria, como o de Santana, obras-primas do arquiteto. O retábulo da Sé é totalmente em madeira, como o era o de Santo Alexandre, a igreja mais importante e belamente decorada que existia na cidade em 1759, momento em que Landi propõe os desenhos para a Sé. Essa afirmação encontra apoio na comprovação da existência de pontos de fixação, na parede, que poderiam ter suportado uma grande estrutura de madeira antes da existência da atual composição - o altar e a pintura semicircular que o completa.

$\mathrm{Se}$ - mesmo parcialmente encoberto pela farta ornamentação e usado apenas para ressaltar o elemento em forma de raios - o nicho foi integrado à composição, as informações de que dispomos não nos permitem afirmá-lo. Pela descrição de Baena, porém, explica-se um último enigma relacionado aos desenhos: o seu desconhecimento. Por que nunca foram notados? Aceitando-se que o fundo da igreja era todo preenchido pela estrutura em madeira, o próprio retábulo os teria escondido por cem anos, até que, em 1881, foi colocado um novo altar. Esta obra em mármore, encomendada a Luca Carimini pelo bispo Dom Macedo Costa, foi executada na Europa sem que o autor conhecesse o local onde seria inserido. A composição do altar ocupa a parede do fundo, deixando sem tratamento o espaço semicircular onde estavam o nicho e os desenhos de 1776. O projetista também pode ter "esquecido" a parede atrás do altar, o que explicaria a contratação de Antonio Urtis "hábil artista mandado vir da Europa por Dom Macedo Costa a fim de forrar de mármore artificial as paredes da capela-mor da Catedral"31. A encomenda da tela Natividade ao "sr Lottini", em 1881, ano em que já se demolia o altar antigo para assentar o novo ${ }^{32}$, destinavase, ao que tudo indica, a criar um elemento de continuidade para a parte superior do altar de mármore projetado por Carimini, que não considerara (ou, mais provavelmente, ignorava) o nicho colonial (Figura 14).

De tantas indefinições, poucas propostas de interpretação podem ser sintetizadas para a presença do nicho da capela-mor. E seriam: ele foi colocado na fase de conclusão das paredes da capela-mor, tinha linhas simples, altura e profundidade para conter uma imagem de grandes dimensões, possivelmente uma imagem da padroeira ${ }^{33}$. Seu fundo seria composto por material não perene, tela ou madeira pintada. Foi incorporado, ou pelo menos considerado, por Landi em seus dois projetos para o altar setecentista. Não consideramos plausível que Landi tivesse projetado o nicho para colocar um esplendor do Espírito Santo, seja pela altura onde foi colocado, seja pela profundidade com que foi construído. Também não parece razoável supor que Landi tenha feito uma composição mista - alvenaria no nicho, combinada com madeira para o resto do altar: em nenhum de seus projetos conhecidos tal associação foi usada; e, na detalhada descrição feita por Baena, contemporânea do altar em madeira, não é sequer mencionada.

Como foi dito inicialmente, nas construções coloniais podemos ler o evoluir não só do prédio em si como dos próprios núcleos urbanos. Seguimos, na Sé, os passos de uma longa construção, interrompida por doenças e por mortes, por querelas entre bispos e o governo português, pelas disputas de poder na 


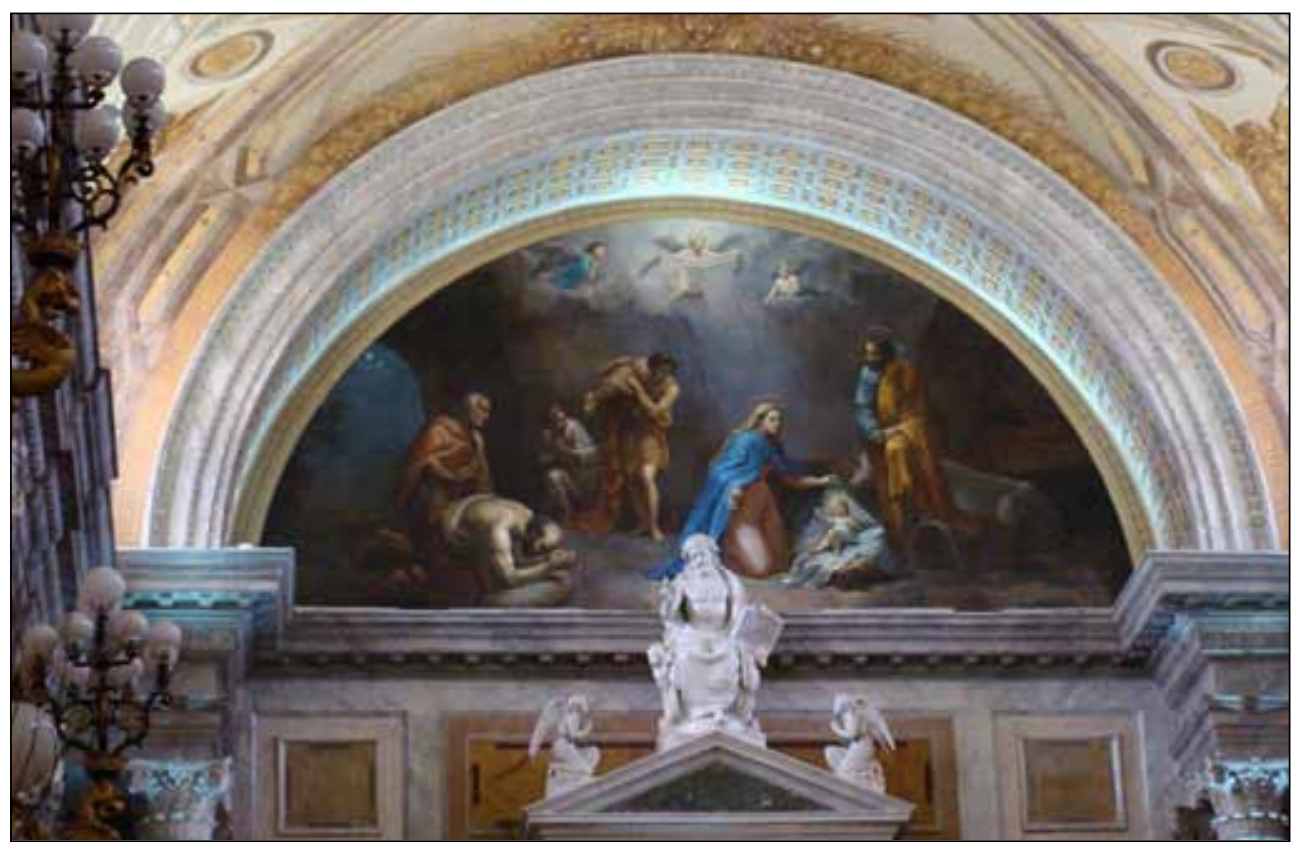

Figura 14 - Detalhe do altar atual. Fotografia de Jussara Derenii, 2011.

distribuição do espólio dos jesuítas, pela instalação de uma Mesa de Inquisição. Vimos a substituição do mestre de obras reais por um acadêmico estrangeiro que, em sua longa permanência na região, galga todos os degraus do reconhecimento social e profissional. Interpretando esses dados, vemos como a pequena cidade, onde os componentes da Comissão de Limites de 1753 chegaram, tornava-se um núcleo urbano de feição monumental, com palácios e igrejas, na qual os poderes religiosos e civis disputavam posições e os estrangeiros ascendiam a patamares anteriormente só permitidos aos colonizadores portugueses. Sabemos que, com inúmeros traços similares, tal trajeto de poder e de disputas percorre o século XIX, dando a esta igreja a feição que agora conhecemos. Nesta leitura, o nicho surge como uma incógnita. Cabe situar, ainda, os desenhos, ou grafites, setecentistas de autor ou de autores desconhecidos, levantando um problema que é muito mais amplo do que os fatos específicos e localizados, relacionados ao nicho da Sé. A questão-chave - e ela permeia a pesquisa da arquitetura do século XVIII no Pará - é: pode-se realmente pensar que Landi dominasse totalmente o panorama construtivo, decorativo, artístico e arquitetônico da Belém colonial? Aos seus contemporâneos, engenheiros militares - Galuzzi, Sambucetti, Gronsfeld, Schwebel, Mardel e outros -, não se encomendaram obras civis e religiosas? Landi, e esta é uma questão especialmente intrigante, não teve auxiliares? Mesmo considerando que o italiano conseguisse projetar todas as obras importantes do período, com a multiplicidade de detalhes que os desenhos conservados mostram, é pouco provável que, sem a ajuda de pintores, de estucadores e artistas de menor projeção - de quem a história não preservou os traços -, ele também conseguisse executá-las.

Annals of Museu Paulista. v. 19. n.1. July.-Dec. 2011. 
34. Agradeço a descoberta deste detalhe à arquiteta Rose Norat, à restauradora $\mathrm{Re}$ nata Maués e a toda a equipe de restauro.
Os desenhos existentes ao lado do nicho remetem exatamente à questão desses inúmeros e desconhecidos protagonistas das construções coloniais, cuja atuação fica obscurecida pelo registro, quase exclusivo, de grandes nomes, aqueles dos autores celebrados em cada período, caso de Antonio Landi no Norte do Brasil. Os desenhos que circundam o nicho da capela-mor da Sé são compostos por riscos soltos, muitas vezes sobrepostos, de difícil identificação. São figuras esboçadas, parecendo rostos, detalhes de arquitetura, animais e plantas. Os motivos arquitetônicos que aparecem nos desenhos são muito simples, volutas e florões. Existem, ainda que dificilmente identificáveis, esboços de pequenas mãos estilizadas, motivo encontrado no desenho do retábulo conservado por Alexandre Rodrigues Ferreira. $O$ belo e sintético desenho de uma pomba ${ }^{34}$, quase encoberta por testes de cor para a pintura do forro, pode ser relacionado com o Espírito Santo representado no esplendor. Anjos, rostos, e as volutas com ornamentos variados, assim como pequenas folhas ou gotas, são indícios de que os desenhos do nicho podem ser, também, relacionados com a execução do altar em madeira proposto por Landi (Figura 15). Tentando sintetizar, neste caso, uma proposta de interpretação para a existência dos desenhos, pode-se aventar a possibilidade de terem sido feitos pelos auxiliares de montagem do altar, ou por seus executores, com a certeza de que seriam encobertos pela estrutura a ser posteriormente colocada.

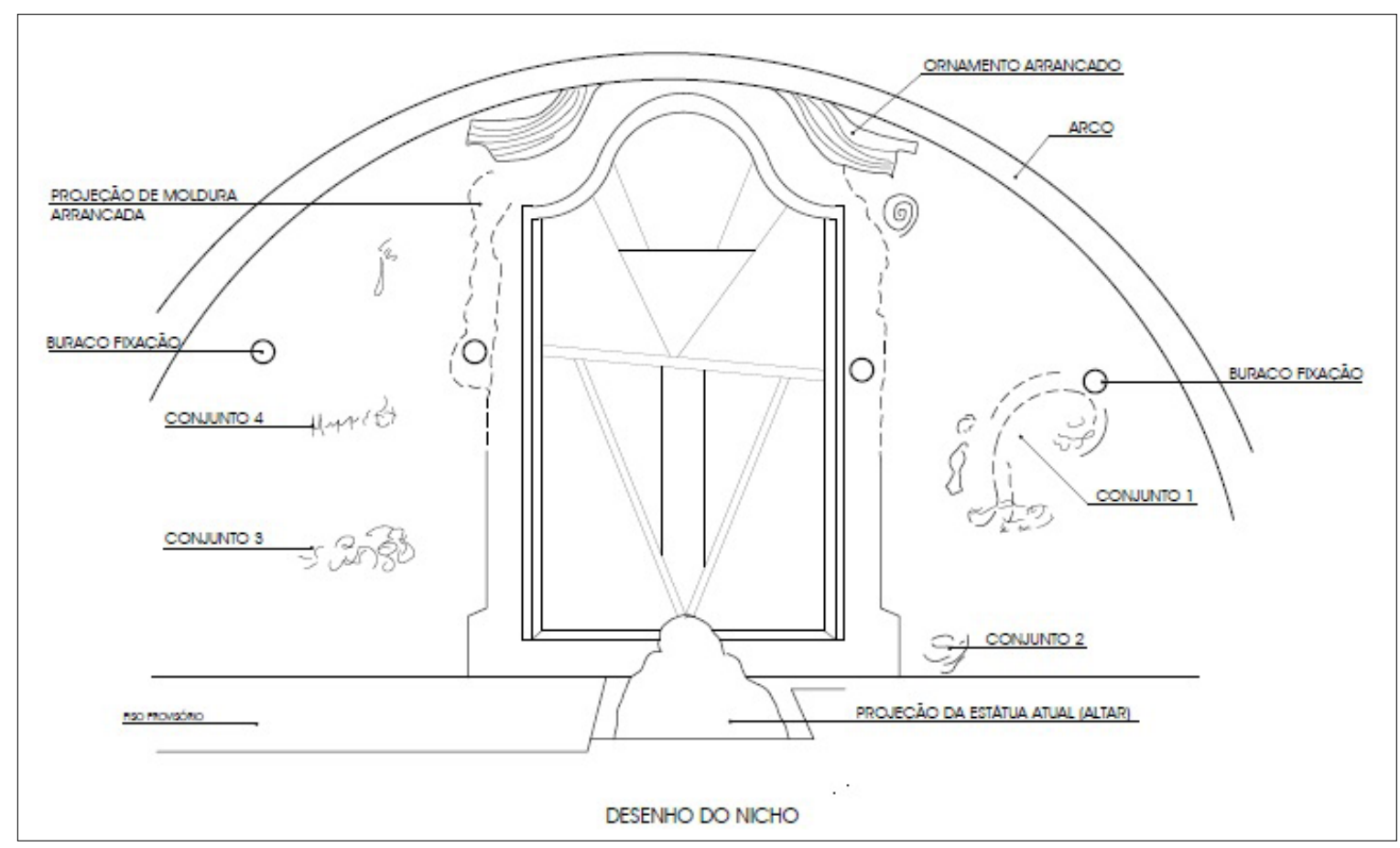

Figura 15 - Localização dos desenhos e detalhes dos mesmos. Representação gráfica de Jussara Derenji, 2011. 
Nada indica, portanto, que os desenhos possam ter sido feitos pelo arquiteto ou sob sua supervisão, embora, no que tange aos desenhos de plantas e de animais, existam várias referências do seu interesse em exercícios sobre o tema. Em 1762, o Bispo do Pará cita uma coleção de desenhos de flores e de frutas que o arquiteto italiano teria executado para oferecer à Universidade de Bolonha. Em 1773, ele oferece ao governador do Mato Grosso uma obra com sua observação da natureza da região, uma descrição de plantas e de animais, que seria acompanhada de desenhos ilustrativos ${ }^{35}$. Na mesma época, estavam sendo terminadas as obras de São João com seus elaborados desenhos de ilusão. Dos trompe l'oeil, concebidos por Landi existem alguns remanescentes, os de São João e, talvez sejam dele as magníficas portas com pintura de ilusão no consistório da própria Sé, mas dos desenhos de animais e plantas não permaneceram traços tornando impossível uma comparação entre eles e os riscados junto ao nicho.

Sabe-se que, em Barcelos, Landi tentou treinar dois jovens militares para ajudá-lo nos desenhos em trompe l'oeil, sem muito sucesso como o próprio Landi relata: "os dois pintores Francesco Xavier de Andrade e o soldado Tomazzo não sabiam colocar o claro-escuro e me coube esboçar eu mesmo toda a obra, e a eles deixei os ornamentos, os festões de flores, e fruta ao natural que fizeram bem mais do que passavelmente" 36 . Teria feito o mesmo em Belém, e os desenhos no alto da Sé seriam exercícios feitos por auxiliares do arquiteto enquanto se ajustava a execução do altar? É conhecido o fato de que, no período colonial, os trabalhos que usavam as mãos, inclusive pintura e escultura, eram atividades consideradas "menores" destinadas, em geral, a escravos índios ou negros ${ }^{37}$. Do século XVI ao século XVIII, ofícios que usavam as mãos faziam os seus praticantes incorrer no chamado "defeito mecânico", que incapacitava, por gerações, os indivíduos da colônia a exercer cargos nas câmaras municipais, em confrarias e irmandades, magistratura e muitos outros ${ }^{38}$.

Considerando este último fato, os desenhos poderiam ser trabalhos desenvolvidos por escravos, auxiliares de Landi? Usava-os em suas fazendas, certamente, mas também está documentado que foram utilizados nas obras de Santana. Seriam esses auxiliares anônimos que, por prazer e distração, dedicaramse a desenhar figuras e colocar a data? No mesmo período, note-se, o uso da mão de obra indígena, mestiça e negra foi registrado na oficina jesuíta do Colégio de Santo Alexandre e sua presença é perceptível na execução de altares e púlpitos $^{39}$. A possibilidade dos desenhos terem sido feitos pelos auxiliares da execução e instalação do altar da Sé tem, como um dos indícios mais importantes, a data - claramente definida como 1776 - existente nos desenhos apostos à parede, período em que a montagem da estrutura do altar estaria sendo feita (Figura 16).

Nada explica, no entanto, os riscos estilizados de largas folhas de plantas, parecendo tajás ${ }^{40}$ regionais e, muito menos, o excepcional desenho de um animal de corpo longo, com manchas na pelagem, representado em atitude quase ameaçadora. Interpretação fantasiosa de um felino, um cachorro do mato talvez, o animal é a peça que não se encaixa, é o indício do mistério, é a prova da transgressão (Figuras 17, 18 e 19).
35. Tais desenhos desapareceram e, em 1963, Leandro Tocantins atribuiu a Landi desenhos similares aos descritos pelo arquiteto italiano e conservados na Biblioteca Municipal do Porto. Em 2000 a citada Biblioteca publicou: Desenhos de História Natural : Zoologia e Botânica do Brasil, com análises dos desenhos de seu acervo. Isabel Mendonça, uma das autoras afirma que os desenhos não são de Landi, aventando a hipótese de serem de autoria de Codina ou Freire, os desenhadores auxiliares da missão de Alexandre Rodrigues Ferreira. ver Isabel Mendonça (2000, p.7-15)

36. Cf Alexandre Rodrigues Ferreira (p. 316). É trecho especifico sobre as pinturas na igreja de Santana, datadas de 1744 , de um relato escrito por Antonio Landi em 1786 sobre sua atuação na cidade de Barcelos; tradução livre da autora.

37 . Ver, a respeito das restrições ao trabalho manual existentes no período colonial, Laima Mesgravis (1983), Charles Boxer(1981), Evaldo Cabral de Mello (2009) e Robert Guedes (2006). Embora a restrição visasse em especial aos comerciantes, que pesavam e mediam, atingia trabalhadores como padeiros e barbeiros, assim como entalhadores, marceneiros e pintores.

38. Cf. Evaldo C. de Mello (2009, p.23, 25, 30, 31).

39. Ver, a respeito, Renata Martins (2009).

40. Plantas da espécie Caladium nativas da região, muito comuns em áreas alagadas. 


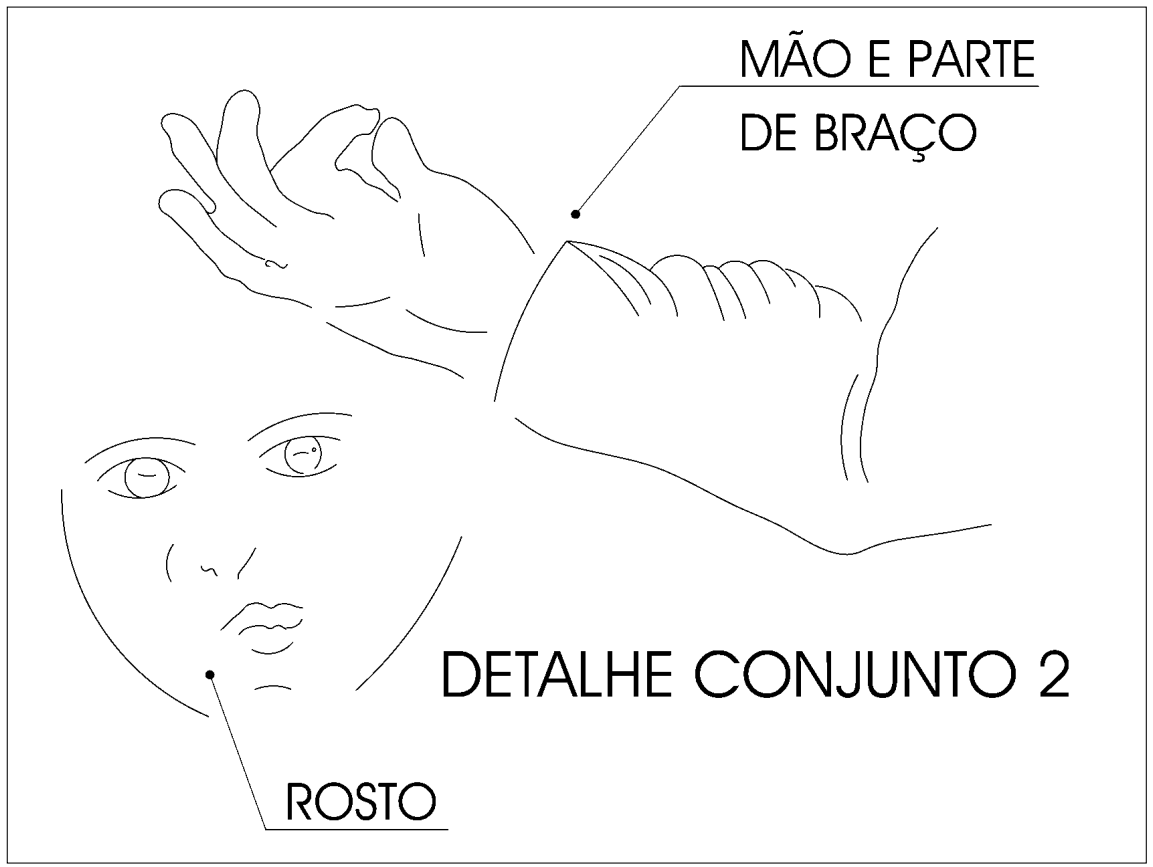

Figura 16 - Detalhe do desenho de rosto e de mão com os dedos se tocando Representação gráfica de Jussara Derenii, 2011.

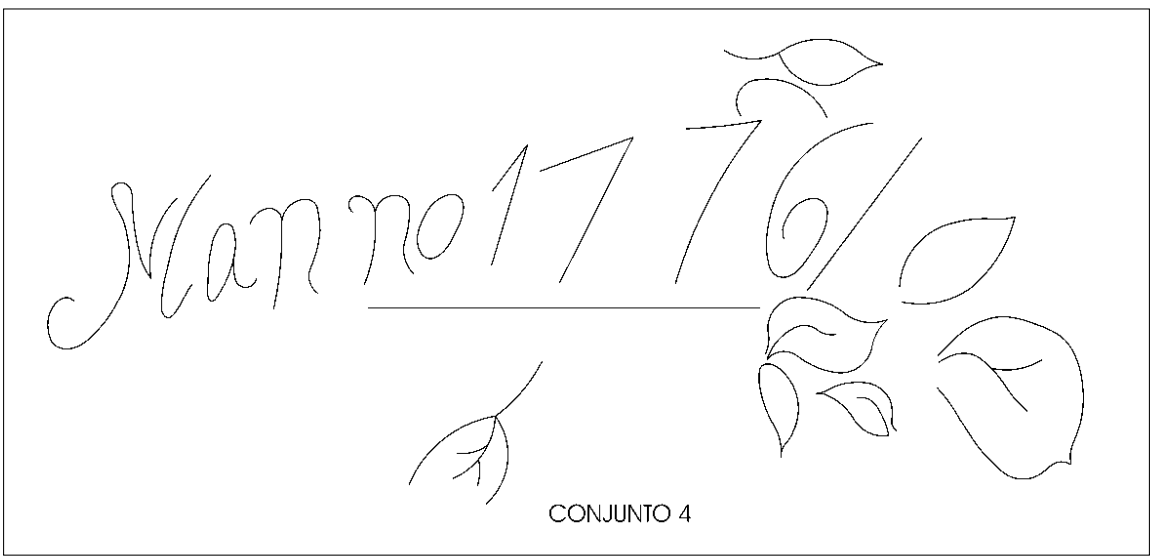

Figura 17 - Detalhe do risco com a data. Representação gráfica de Jussara Derenji, 2011. 


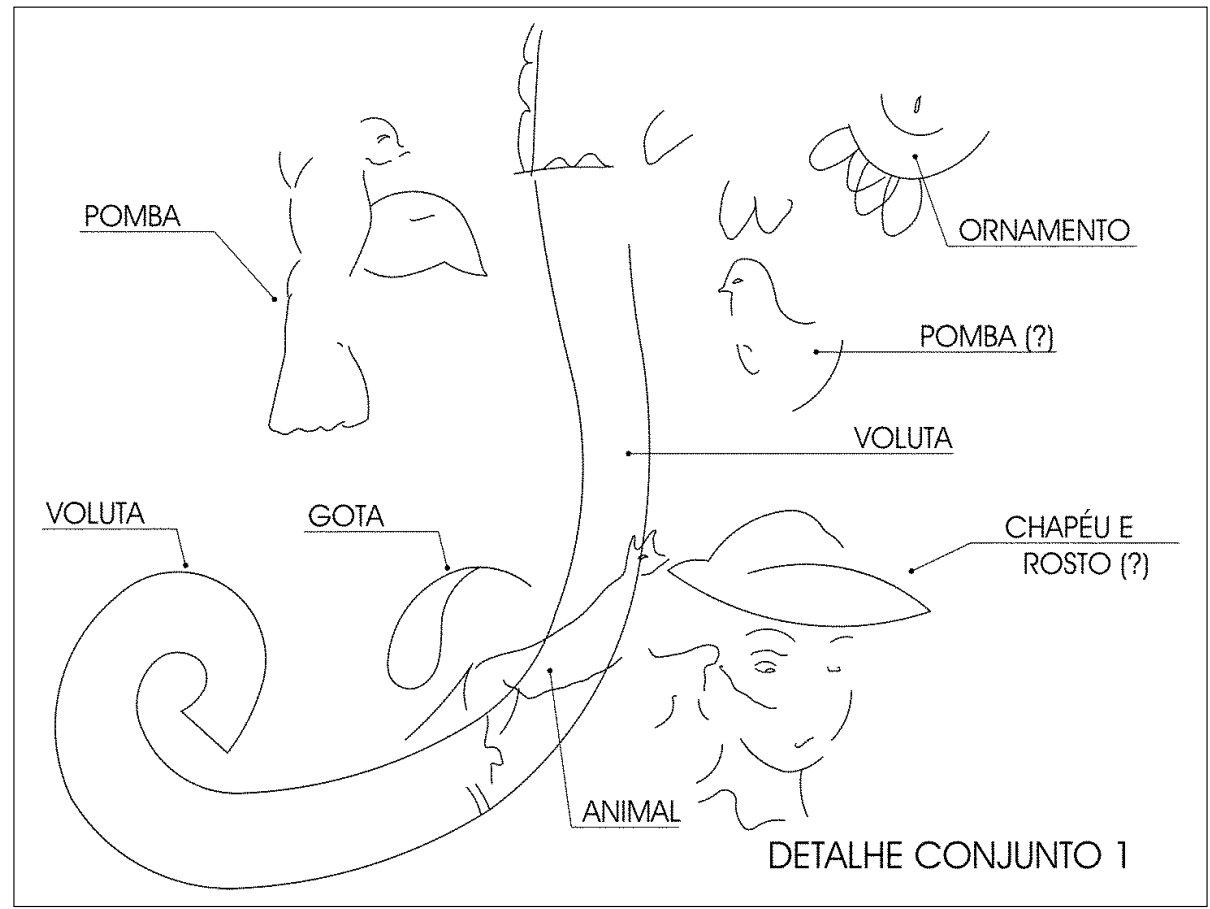

Figura 18 - Desenhos diversos. Representação gráfica Jussara Derenii, 2011.

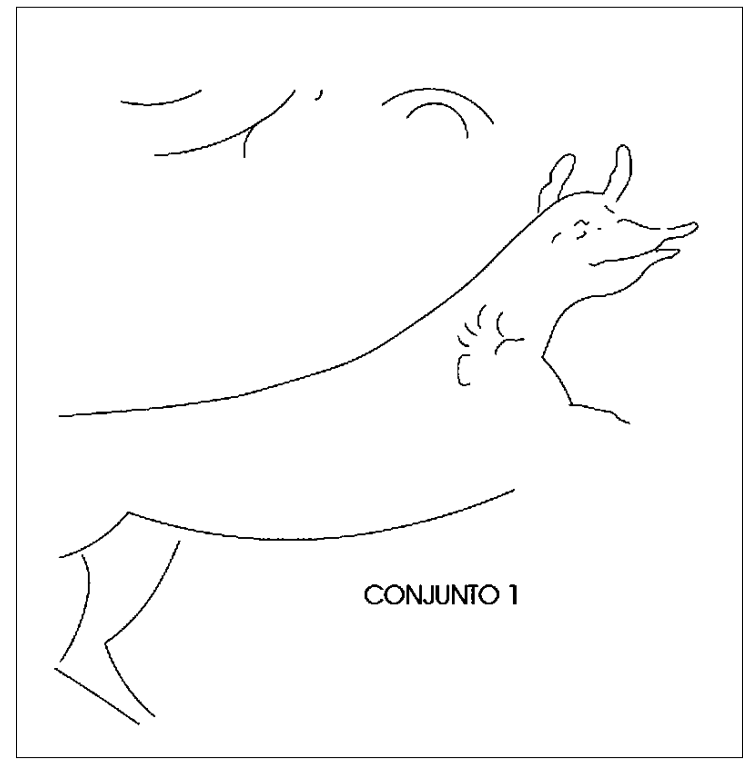

Figura 19 - Detalhe aumentado do desenho de animal. Representação gráfica de Jussara Derenii, 2011. 
41. Em várias ocasiões, Jean Baudrillard analisa a intenção de protesto do grafiti no mundo moderno. Segundo o autor, no início do período (anos 1950), nos Estados Unidos, o autor do grafiti posiciona-se como contestador: sou fulano, estive aqui e minha posição é esta. Aos poucos, a intenção se reduz a: sou fulano e estive aqui; $c f$. Jean Baudrillard (1988, p. 25).
É tentador imaginar - mas não é essa a tarefa do historiador, a quem cabe analisar fatos - que mãos negras ou indígenas deixaram esses traços transgressores na obra da Sé. Duzentos e trinta e três anos depois, eles nos lembrariam que as igrejas e os palácios, os edifícios grandiosos da nossa história colonial foram feitos por artistas eruditos e de memória cuidadosamente preservada, mas também se devem ao trabalho de anônimos talentos que, como na análise de grafites modernos feita por Baudrillard ${ }^{41}$, queriam apenas dizer: eu estive aqui.

\section{REFERÊNCIAS}

AMARAL LAPA, José R. do. Livro da Visitação do Santo Oficio da Inquisição ao Estado do Grão-Pará. Petrópolis:Vozes, 1978.

BAENA,António L. M. Compêndio das Eras da Província do Pará. Belém: UFPA, 1969.

BAUDRILLARD, Jean. El otro por si mismo. Barcelona:Anagrama, 1988.

BAZIN, Germain. A arquitetura religiosa Barroca no Brasil. Rio de Janeiro: Record, 1956. 2v.

BOXER, Charles. O Império Colonial Português. Lisboa: Edições 70, 1981.

CRUZ, Ernesto. Igrejas de Belém. Belém: Prefeitura Municipal de Belém, 1974.

DERENJI, Jussara da Silveira; DERENJI, Jorge. Igrejas, palácios e palacetes de Belém. Brasília: IPHAN; Monumenta, 2009.

FERREIRA, Alexandre Rodrigues. Viagem filosófica pelas capitanias do Grão-Pará, Rio Negro, Mato Grosso e Cuyabá, 1783-1792. Iconografia. Rio de Janeiro: Conselho Federal de Cultura, 1972.

.Viagem Filosófica ao Rio Negro. Belém: Museu Paraense Emilio Göeldi, 1983.

GUEDES, Roberto. Ofícios mecânicos e mobilidade social. Séculos XVII e XIX. Topoi, Rio de Janeiro, v. 7, p. 379-422, 2006.

LEAL,Américo [monsenhor]. A Igreja da Sé. Belém: Conselho de Cultura, 1979.

MARCOY, Paul [Laurent Saint-Cricq]. Voyage à travers l'Amérique du Sud, de l'Océan Pacifique a l'Océan Atlantique. Paris: Hachette, 1867.

MARTINS, Renata M. de A. Tintas da terra, tintas do reino: arquitetura e arte nas missões jesuíticas do Grão-Pará. 2009. Tese (Doutorado em Arquitetura e Urbanismo) - Faculdade de Arquitetura e Urbanismo da Universidade de São Paulo, São Paulo, 2009.

MEIRA FILHO, Augusto. Contribuição à bistoria de Belém. Belém: Governo do Estado do Pará, 1973.

.Evolução histórica de Belém do Grão-Pará. Belém: Grafisa,1976. 2v. 
MELLO, Evaldo C. de. O nome e o sangue. São Paulo: Companhia de Bolso, 2009.

MELLO JUNIOR, Donato. Iconografia de Belém do Grão-Pará. Belém: Sociedade dos Amigos de Belém, 1970.

MENDONÇA, Isabel M. G. Antonio José Landi e a festa barroca na Amazônia. In: BONDI Mario (Org.). Amazonia Felsínea. Antonio José Landi: itinerário artístico e científico de um arquitecto bolonhês na Amazónia do século XVIII. Lisboa: Comissão Nacional para os Descobrimentos Portugueses, 1999a.

Dados cronológicos vida e obra de Antonio Landi. In: ; BONDI, Mario (Org.). Amazonia Felsínea. Antonio José Landi: itinerário artístico e científico de um arquitecto bolonhês na Amazónia do século XVIII. Lisboa: Comissão Nacional para os Descobrimentos Portugueses, $1999 \mathrm{~b}$.

Os desenhos de Historia Natural: zoologia e botânica do Brasil e o manuscrito de Antonio José Landi da Biblioteca Municipal do Porto. In: COSTA, Jorge (Org.). Zoologia E Botanica do Brasil. Desenhos de Historia Natural. Porto: Biblioteca Municipal do Porto, 2000.

Antonio José Landi (1713/1791). Um artista entre dois continentes. Coimbra: Gulbenkian. 2003.

MENDONÇA, Marcos Carneiro de. A Amazônia na Era Pombalina,1751 -1759. Rio de Janeiro: Instituto Histórico e Geográfico Brasileiro,1963.3 v.

MESGRAVIS, Laima. Os aspectos estamentais da estrutura social da Colônia. Estudos Econômicos, São Paulo, n. 13 (especial), p. 799-811, 1983.

NORAT, Roseane. Catedral de Belém: arquitetura e restauro. Belém, 2009. (Inédito).

OLIVEIRA, Myriam R. O rococó religioso no Brasil e seus antecedentes europeus. São Paulo: Cosac \& Naify, 2003

PARÁ. Catedral Metropolitana de Belém. Estudo de esboços. Nicho do altar-mor. Relatório Governo do Estado do Pará. Belém: Secretaria de Estado de Cultura; Diretoria de patrimônio; Departamento de Projetos, 2009. (Inédito).

REIS FILHO, Nestor Goulart. Imagens de Vilas e Cidades do Brasil Colonial. São Paulo: Edusp; Imprensa Oficial do Estado; Fapesp, 2000.

SMITH, Robert C. El Palacio de los gobernadores de Gran-Pará. Anales del Instituto de Arte Americano e investigaciones estéticas. Buenos Aires: Instituto de Artes e Investigaciones Estéticas, 1951.

Artigo apresentado em 9/2011. Aprovado em 12/2011.

Annals of Museu Paulista. v. 19. n.1. July.-Dec. 2011. 